\title{
HYDROLATES - BY-PRODUCTS OF ESSENTIAL OIL DISTILLATION: CHEMICAL COMPOSITION, BIOLOGICAL ACTIVITY AND POTENTIAL USES
}

Milica G. Aćimović ${ }^{*}$, Vele V. Tešević ${ }^{2}$, Katarina T. Smiljanić2 ${ }^{2}$ Mirjana T. Cvetković3 Jovana M. Stanković ${ }^{3}$, Biljana M. Kiprovski ${ }^{1}$, Vladimir S. Sikora ${ }^{1}$

1 Institute of Field and Vegetable Crops, Novi Sad, Serbia

2 University of Belgrade, Faculty of Chemistry, Belgrade, Serbia

3 University of Belgrade, Institute of Chemistry, Technology and Metallurgy, Belgrade, Serbia

Hydrolates, also referred to as hydrosols, floral or distillate waters, as well as aromatic waters, are produced in the same isolation process with essential oils by steam distillation. A small amount of essential oil constituents is dissolved in hydrolates providing specific organoleptic properties and flavor, as well as biological activity which makes them useful as raw material in many industries. Their popularity is still on the rise, especially in aromatherapy. The objective in this review is to analyze the chemical compositions of hydrolates and their corresponding essential oils, as well as biological activity of hydrolates (antimicrobial, antioxidant and antiinflamatory) and potential uses, not only in food industry for flavoring, and preservation of freshcut fruits and vegetables, but also as functional (soft) drinks. However, hydrolates can be used in aromatherapy and cosmetics, as well as in organic agriculture and aquaculture.
(REVIEW PAPER)

UDC 66.048:665.52

DOI: $10.5937 /$ savteh2002054A
Keywords: Hydrolates, Hydrosols, Aromatic waters, Floral waters, Distillate waters

\section{Introduction}

Hydrolates, also referred to as hydrosols, floral or distillate waters, as well as aromatic waters, are produced in the same isolation process with essential oils by steam distillation. During industrial distillation, water is evaporated simultaneously with the essential oil. After condensation of the vapors in contact with cold vessels or tubes, the liquefied components are separated into two phases inside a collecting Florentine vessel: essential oil and the hydrolate $[1,2,3]$. However, a small amount of essential oil constituents dissolves in hydrolates, precious oxygenated compounds, providing specific organoleptic properties and flavor, as well as biological activity which makes them useful for food and cosmetic industries [4,5].

The essential oil dissolved in hydrolates is usually discarded. This leads to the loss of dissolved essential oil. This phenomenon was observed in many other aromatic crops and attempts were made to recover the dissolved oil from hydrolates. Recovered essential oils are often referred to as secondary oils. The methods used for recovering aromatic oils from hydrolates were: cohobation, extraction with diethyl ether, adsorbing oil constituents on to an adsorbent followed by ethanol extraction and poroplast technique [6]. Furthermore, the loss of oxygenated constituents in distillation water makes the aroma of primary oils incomplete in terms of organoleptic richness and fullness. When the recovered oil was blended with the primary oil, the olfactory evaluation of the blended oil indicated that it had a much more natural and richer aroma than the primary oil. Alternatively, hydrolates could also be used for the isolation of pure compounds [5].

Many different hydrolates are used commercially, mainly as cosmetic ingredients, as well as in food industry. Their popularity is still on the rise, especially in aromatherapy. These natural products constitute promising, new and valuable sources, which may be approved as raw material in many different products [7].

Coincidentally, short time before work was started on this contribution, a review covering a similar field was published [8]. Not meaning to duplicate this work, the intention was still to complement it. However, the above-mentioned excellent review is mainly devoted to the discussion of the biological activity of hydrolates and their potential as antimicrobials for food applications.

The objective in this review is to analyze the chemical compositions of hydrolates and their corresponding essential oils, as well as biological activity of hydrolates (antimicrobial, antioxidant and antiinflamatory) and potential uses, not only in food industry for flavoring, and preservation of fresh-cut fruits and vegetables, but also as functional (soft) drinks. Furthermore, hydrolates can be used in aromatherapy and cosmetics, as well as in organic agriculture.

\section{Chemical composition}

Hydrolates usually contain less than $1 \mathrm{~g} \mathrm{~L}^{-1}$ (i.e. $0.10 \%$ ) of water soluble aromatic compounds (i.e. volatile organic compounds) from essential oil, that remain dissolved in the water phase, whereas hydrolates which included $0.17 \%$ aromatic compounds that remained after the water fraction,

\footnotetext{
*Author address: Milica Aćimović, Institute of Field and Vegetable Crops,

21000 Novi Sad, Maksima Gorkog 30, Serbia

E-mail: milica.acimovic@ifvcns.ns.ac.rs

The manuscript received: Jun, 01, 2020.

Paper accepted: Jul, 13, 2020.
} 
are highly aromatic and their composition was rather different than of the essential oil's [9]. However, literature review of absolute quantification of the water-soluble aromatic compounds from different hydrolates in $\mathrm{mg} \mathrm{L}^{-1}$ is shown in Table 1.

Table 1. Content of Volatile Organic Compounds (VOCs) in hydrolates (mg L-1)

\begin{tabular}{lccc}
\hline Plant material & Plant part & Content of VOC $\left.\mathbf{~} \mathbf{m g ~ L}^{-\mathbf{1}}\right)$ & Reference \\
\hline Abies alba & seed & 11 & {$[7]$} \\
Abies balsamea & branches & 190 & {$[10]$} \\
Abies koreana & seed & 37 & {$[7]$} \\
Asarum canadense & root & 590 & {$[11]$} \\
Citrus aurantium & peel & 212 & {$[1]$} \\
Comptonia peregrina & aerial parts & 296 & {$[12]$} \\
Cymbopogon citratus & leaves & $\sim 249$ & {$[1]$} \\
Eucalyptus citrodora & leaves & $\sim 165$ & {$[1]$} \\
Eugenia caryophyllata & buds & $\sim 1012$ & {$[1]$} \\
Ledum groenlandicum & aerial parts & 630 & {$[12]$} \\
Melissa officinalis & aerial parts & 240 & {$[11]$} \\
Mentha piperita & aerial parts & 235 & {$[13]$} \\
Mentha spicata & aerial parts & $\sim 397$ & {$[1]$} \\
Myrica gale & aerial parts & 110 & {$[12]$} \\
Ocimum basilicum & aerial parts & $\sim 360$ & {$[1]$} \\
Picea glauca & branches & 933 & {$[10,13]$} \\
Picea mariana & branches & 260 & {$[10]$} \\
Solidago puberula & aerial parts & 241 & {$[13]$} \\
\hline$(\sim)$ calculated according to presented data & & &
\end{tabular}

Table 2. Analysis of essential oils and Volatile Organic Compounds (VOCs) from corresponding hydrolates of different plant samples

\begin{tabular}{|c|c|c|c|c|c|}
\hline Plant material & Plant part & $\begin{array}{l}\text { Country } \\
\text { of origin }\end{array}$ & Essential oil & Hydrolate & $\begin{array}{l}\text { Refer } \\
\text { ence }\end{array}$ \\
\hline Abies alba & seed & Poland & $\begin{array}{l}\text { limonene }(82.9 \%) \\
\text { camphene }(6.3 \%)\end{array}$ & $\begin{array}{l}\text { selin-6-en-4-ol }(51.7 \%) \\
\beta \text {-himachalol }(14.5 \%) \\
T \text {-cadinol }(10.9 \%) \\
\text { intermedeol }(9.8 \%)\end{array}$ & {$[7]$} \\
\hline Abies balsamea & branches & Canada & $\begin{array}{l}\beta \text {-pinene }(33.5 \%) \\
\delta \text {-3-carene }(14.0 \%) \\
\alpha \text {-pinene }(11.3 \%) \\
\text { bornyl acetate }(10.0 \%) \\
\beta \text {-phellandrene }(7.2 \%) \\
\text { limonene }(7.1 \%)\end{array}$ & $\begin{array}{l}\text { a-terpineol }(41.6 \%) \\
\text { maltol }(8.6 \%) \\
\text { borneol }(6.4 \%) \\
\text { bornyl acetate }(5.1 \%)\end{array}$ & [10] \\
\hline Abies koreana & seed & Poland & $\begin{array}{l}\text { limonene }(53.7 \%) \\
\alpha \text {-pinene }(12.1 \%) \\
\text { bornyl acetate }(12.1 \%) \\
\text { camphene }(11.2 \%)\end{array}$ & $\begin{array}{l}\text { intermedeol }(76.7 \%) \\
\text { selin-6-en-4-ol }(2.4 \%) \\
\text { bornyl acetate }(2.0 \%)\end{array}$ & [7] \\
\hline Asarum canadense & root & Canada & $\begin{array}{l}\text { methyl eugenol }(38.5 \%) \\
\text { linalool }(19.4 \%) \\
\alpha \text {-terpineol }(5.9 \%)\end{array}$ & $\begin{array}{l}\text { linalool }\left(106 \mathrm{mg} \mathrm{L}^{-1}\right) \\
\alpha \text {-terpineol }\left(115 \mathrm{mg} \mathrm{L}^{-1}\right) \\
\text { methyl eugenol }\left(89 \mathrm{mg} \mathrm{L}^{-1}\right)\end{array}$ & [11] \\
\hline Bunium persicum & seed & Iran & $\begin{array}{l}\text { cuminic aldehyde }(26.8 \%) \\
\text { y-terpinene }(24.03 \%) \\
\text { y-terpinene-7-al }(14.2 \%) \\
\text { o-cymene }(9.2 \%)\end{array}$ & $\begin{array}{l}\text { cuminol }(32.5 \%) \\
\text { cuminic aldehyde }(29.4 \%) \\
\text { a-terpinen-7-al }(19.4 \%)\end{array}$ & [18] \\
\hline Cerasus serrulata & flowers & China & $\begin{array}{l}\text { benzaldehyde }(42.1 \%) \\
\text { tricosane }(27.7 \%) \\
\text { pentacosane }(19.0 \%)\end{array}$ & $\begin{array}{l}\text { benzaldehyde }(64.3 \%) \\
\text { mandelonitrile }(12.4 \%)\end{array}$ & [19] \\
\hline Cerasus subhirtella & flowers & China & $\begin{array}{l}\text { benzaldehyde }(31.2 \%) \\
\text { tricosane }(23.1 \%) \\
\text { pentacosane }(23.2 \%)\end{array}$ & $\begin{array}{l}\text { benzaldehyde }(67.5 \%) \\
\text { mandelonitrile }(12.5 \%)\end{array}$ & [19] \\
\hline Citrus aurantium & peel & Egypt & $\begin{array}{l}\text { linalool }(52.8 \%) \\
\text { linalyl acetate }(9.5 \%)\end{array}$ & $\begin{array}{l}\text { linalyl acetate }(46.7 \%) \\
\text { linalool }(32.7 \%)\end{array}$ & [1] \\
\hline Citrus ladanifer & $\begin{array}{l}\text { aerial } \\
\text { parts }\end{array}$ & Portugal & $\begin{array}{l}\alpha \text {-pinene }(26.3 \%) \\
\text { camphene }(19.0 \%) \\
\text { bornyl acetate }(5.0 \%) \\
\text { limonene }(3.8 \%)\end{array}$ & $\begin{array}{l}2,6,6 \text {-trimethyl cyclohexane } \\
(10.8 \%) \\
\text { E-pinocarveol }(5.2 \%) \\
\text { borneol }(6.2 \%)\end{array}$ & [20] \\
\hline $\begin{array}{l}\text { Comptonia } \\
\text { peregrina }\end{array}$ & $\begin{array}{l}\text { aerial } \\
\text { parts }\end{array}$ & Canada & $\begin{array}{l}\beta \text {-caryophyllene }(27.0 \%) \\
1,8 \text {-cineole andmyrcene } \\
(9.7 \%) \\
\text { myrcene }(7.3 \%)\end{array}$ & $\begin{array}{l}\text { 1,8-cineole }(15.8 \%) \\
\text { E-2-hexen-1-ol }(14.2 \%) \\
\text { Z-3-hexen-1-ol }(12.3 \%) \\
\alpha \text {-terpineol }(9.8 \%) \\
\text { linalool }(6.3 \%) \\
\text { terpinen-4-ol }(6.2 \%)\end{array}$ & [12] \\
\hline
\end{tabular}




\begin{tabular}{|c|c|c|c|c|c|}
\hline $\begin{array}{l}\text { Cupressus } \\
\text { lusitanica }\end{array}$ & $\begin{array}{l}\text { aerial } \\
\text { parts }\end{array}$ & Portugal & $\begin{array}{l}\text { a-pinene }(24.8 \%) \\
\text { sabinene }(15.6 \%) \\
\text { limonene }(13.6 \%) \\
\delta \text {-3-carene }(12.2 \%)\end{array}$ & $\begin{array}{l}\text { umbellulone }(47.9 \%) \\
\text { terpinen-4-ol }(23.8 \%)\end{array}$ & [20] \\
\hline $\begin{array}{l}\text { Cymbopogon } \\
\text { citratus }\end{array}$ & leaves & Egypt & $\begin{array}{l}\text { geranial }(36.9 \%) \\
\text { neral }(34.5 \%) \\
\text { linalool }(9.3 \%)\end{array}$ & $\begin{array}{l}\text { geranial }(43.8 \%) \\
\text { neral }(31.9 \%)\end{array}$ & [1] \\
\hline $\begin{array}{l}\text { Daucus carota } \\
\text { subsp. sativus }\end{array}$ & $\begin{array}{l}\text { aerial } \\
\text { parts }\end{array}$ & Algeria & $\begin{array}{l}\text { alismol }(15.2 \%) \\
\alpha \text {-humulene }(9.5 \%) \\
\beta \text {-ionone }(8.2 \%)\end{array}$ & $\begin{array}{l}\text { caryophyllene oxide }(9.8 \%) \\
\text { p-cymen-8-ol }(8.9 \%)\end{array}$ & [21] \\
\hline $\begin{array}{l}\text { Daucus carota } \\
\text { subsp. sativus }\end{array}$ & root & Algeria & geranyl linalool (50.3\%) & $\begin{array}{l}\text { myristicine }(17.8 \%) \\
\text { E-methyl-iso-eugenol } \\
(16.6 \%) \\
\text { methyl-eugenol }(11.9 \%)\end{array}$ & [21] \\
\hline Eucalyptus alba & leaves & Senegal & $\begin{array}{l}\text { 1,8-cineole }(37.2 \%) \\
\alpha \text {-pinene }(22.7 \%) \\
\text { limonene }(7.0 \%)\end{array}$ & $\begin{array}{l}\text { 1,8-cineole }(39.1 \%) \\
\text { E-pinocarveol }(19.3 \%) \\
\text { pinocarvone }(6.8 \%)\end{array}$ & [22] \\
\hline $\begin{array}{l}\text { Eucalyptus } \\
\text { camaldulensis }\end{array}$ & leaves & Senegal & $\begin{array}{l}1,8 \text {-cineole }(50.0 \%) \\
\text { limonene }(17.8 \%) \\
\alpha \text {-pinene }(9.3 \%) \\
p \text {-cymene }(7.4 \%)\end{array}$ & $\begin{array}{l}\text { 1,8-cineole }(52.6 \%) \\
\alpha \text {-terpineol }(6.6 \%) \\
\text { Z-p-mentha-1-(7)-8-dien-2ol } \\
(5.1 \%)\end{array}$ & [22] \\
\hline Eucalyptus cinerea & leaves & Italy & $\begin{array}{l}1,8 \text {-cineole }(83.8 \%) \\
\text { limonene }(4.7 \%) \\
\text { a-terpineol }(2.8 \%)\end{array}$ & $\begin{array}{l}\text { 1,8-cineole }(88.4 \%) \\
\text { a-terpineol }(6.2 \%)\end{array}$ & [23] \\
\hline $\begin{array}{l}\text { Eucalyptus } \\
\text { citrodora }\end{array}$ & leaves & Egypt & $\begin{array}{l}\text { citronellal }(34.3 \%) \\
\text { citronellol }(8.9 \%)\end{array}$ & $\begin{array}{l}\text { citronellal }(76.1 \%) \\
\text { citronelool }(9.9 \%)\end{array}$ & [1] \\
\hline Eucalyptus parvula & leaves & Italy & $\begin{array}{l}\text { 1,8-cineole }(87.8 \%) \\
\text { limonene }(3.3 \%) \\
\alpha \text {-terpineol }(3.1 \%)\end{array}$ & $\begin{array}{l}\text { 1,8-cineole }(89.7 \%) \\
\text { a-terpineol }(5.9 \%)\end{array}$ & [23] \\
\hline $\begin{array}{l}\text { Eucalyptus } \\
\text { pulverulenta }\end{array}$ & leaves & Italy & $\begin{array}{l}1,8 \text {-cineole }(86.4 \%) \\
\text { limonene }(4.0 \%) \\
\text { a-terpineol }(2.1 \%)\end{array}$ & $\begin{array}{l}\text { 1,8-cineole }(90.0 \%) \\
\text { a-terpineol }(4.3 \%)\end{array}$ & [23] \\
\hline $\begin{array}{l}\text { Eucalyptus } \\
\text { tereticornis }\end{array}$ & leaves & Senegal & $\begin{array}{l}p \text {-cymene }(45.5 \%) \\
1,8 \text {-cineole }(22.9 \%) \\
\text { limonene }(5.4 \%)\end{array}$ & $\begin{array}{l}1,8 \text {-cineole }(30.7 \%) \\
\alpha \text {-terpineol }(8.8 \%) \\
\text { E-pinocarveol }(7.6 \%) \\
\text { carvacrol }(7.0 \%)\end{array}$ & [22] \\
\hline $\begin{array}{l}\text { Eugenia } \\
\text { caryophyllata }\end{array}$ & buds & Egypt & eugenol $(96.6 \%)$ & eugenol $(84.4 \%)$ & [1] \\
\hline Laurus nobilis & leaves & Argentina & $\begin{array}{l}1,8 \text {-cineole }(45.0 \%) \\
\text { linalool }(12.8 \%)\end{array}$ & $\begin{array}{l}\text { 1,8-cineole }(54.4 \%) \\
\text { a-terpineol }(11.8 \%) \\
\text { methyl eugenol }(10.9 \%) \\
\text { linalool }(8.1 \%) \\
\text { terpinen-4-ol }(7.6 \%) \\
\text { eugenol }(6.0 \%)\end{array}$ & [24] \\
\hline Lavandulaangustifolia & flowers & Poland & $\begin{array}{l}\text { linalool }(30.6 \%) \\
\text { linalyl acetate }(14.2 \%) \\
\text { geraniol }(5.3 \%)\end{array}$ & $\begin{array}{l}\text { linalool }(34.1 \%) \\
\alpha \text {-terpineol }(9.9 \%) \\
\text { borneol }(7.1 \%) \\
\text { terpinen-4-ol }(5.9 \%)\end{array}$ & $\begin{array}{l}{[25,} \\
26]\end{array}$ \\
\hline $\begin{array}{l}\text { Lavandula } \\
\text { intermedia }\end{array}$ & flowers & Turkey & $\begin{array}{l}\text { linalyl acetate }(47.7 \%) \\
\text { linalool }(34.0 \%)\end{array}$ & $\begin{array}{l}\text { linalool }(55.6 \%) \\
\text { borneol }(13.5 \%) \\
\text { camphor }(13.4 \%) \\
1,8 \text {-cineole }(9.8 \%) \\
\text { linalool oxide }(6.0 \%)\end{array}$ & [27] \\
\hline $\begin{array}{l}\text { Lavandula } \\
\text { intermedia }\end{array}$ & flowers & Italy & $\begin{array}{l}\text { linalool }(35.8 \%) \\
1,8 \text {-cineole }(19.8 \%) \\
\text { a-pinene }(8.7 \%) \\
\text { linalyl acetate }(7.5 \%)\end{array}$ & $\begin{array}{l}\text { 1,8-cineole }(52.9 \%) \\
\text { camphor }(19.6 \%) \\
\text { linalool }(12.6 \%)\end{array}$ & [28] \\
\hline Ligusticum porteri & root & Oregon & $\begin{array}{l}\text { sabinene }(9.0-15.5 \%) \\
p \text {-cymene }(6.5-9.7 \%) \\
\text { viridene }(19.4 \%) \\
\text { E-sabinyl acetate }(22.6 \%)\end{array}$ & $\begin{array}{l}\text { terpinen-4-ol }\left(16.5 \mathrm{mg} \mathrm{L}^{-1}\right) \\
\text { hexanal }\left(2.5 \mathrm{mg} \mathrm{L}^{-1}\right) \\
\text { furfural }\left(2.0 \mathrm{mg} \mathrm{L}^{-1}\right) \\
p \text {-cymen-8-ol }\left(2.5 \mathrm{mg} \mathrm{L}^{-1}\right)\end{array}$ & [17] \\
\hline Lippia alba & leaves & Columbia & $\begin{array}{l}\text { carvone }(41.6 \%) \\
\text { limonene }(40.6 \%) \\
\text { germacrene } D(8.1 \%)\end{array}$ & carvone $(92.7 \%)$ & [29] \\
\hline Melissa officinalis & $\begin{array}{l}\text { aerial } \\
\text { parts }\end{array}$ & Canada & $\begin{array}{l}\text { geranial }(24.3 \%) \\
\text { neral }(17.5 \%) \\
\text { geraniol }(8.5 \%)\end{array}$ & $\begin{array}{l}\text { geraniol }\left(42 \mathrm{mg} \mathrm{L}^{-1}\right) \\
\mathrm{Z} \text {-3-hexen-1-ol }\left(28 \mathrm{mg} \mathrm{L}^{-1}\right) \\
\text { linalool }\left(18 \mathrm{mg} \mathrm{L}^{-1}\right) \\
\text { geranial }\left(13 \mathrm{mg} \mathrm{L}^{-1}\right) \\
\alpha \text {-terpineol }\left(11 \mathrm{mg} \mathrm{L}^{-1}\right) \\
\text { E-p-menth-2-ene-1,8-diol } \\
\left(11 \mathrm{mg} \mathrm{L}^{-1}\right) \\
\text { Z-p-menth-2-ene-1,8-diol (8 } \\
\left.\mathrm{mg} \mathrm{L}^{-1}\right)\end{array}$ & [11] \\
\hline
\end{tabular}




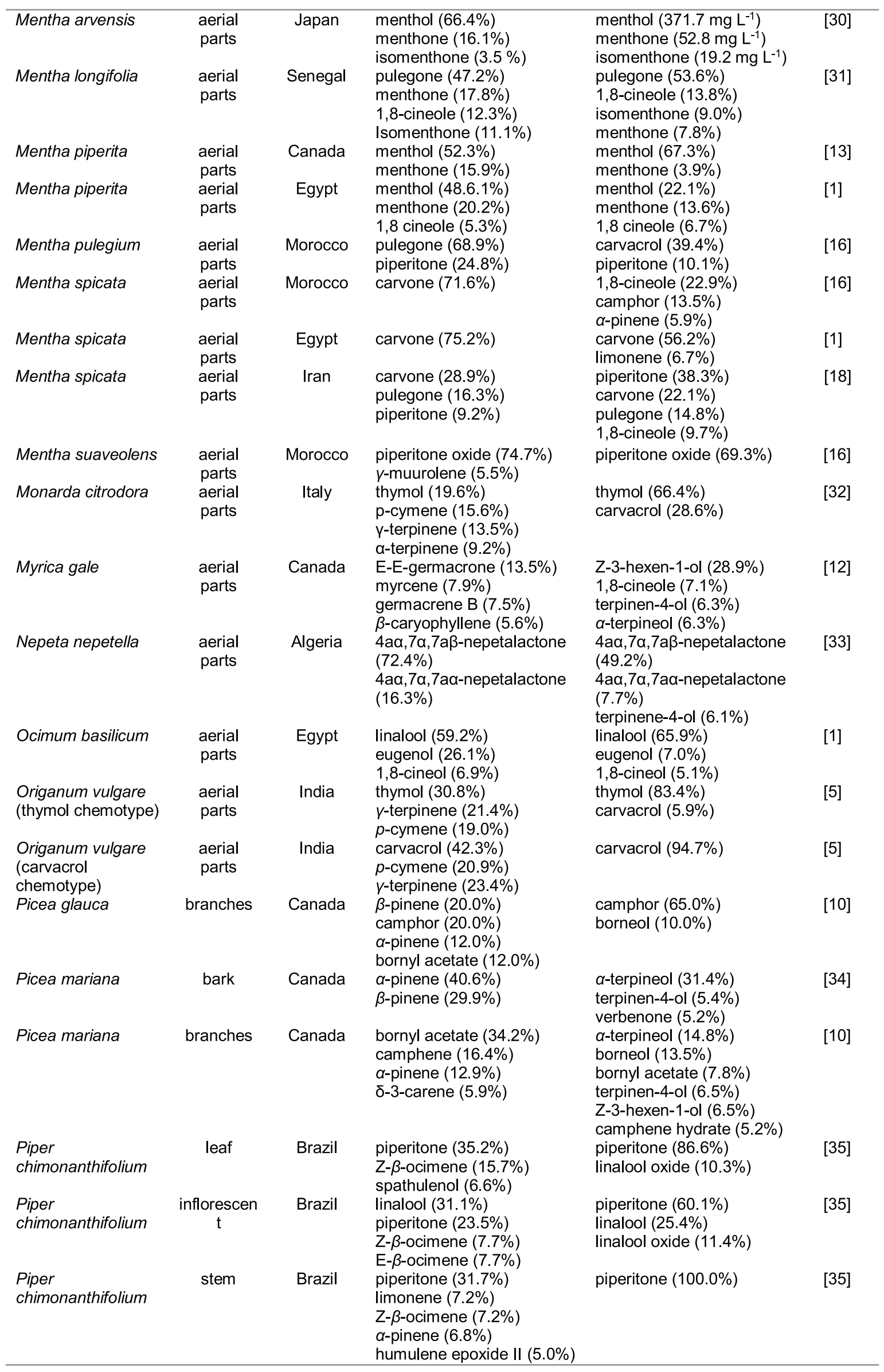




\begin{tabular}{|c|c|c|c|c|c|}
\hline $\begin{array}{l}\text { Psoralea } \\
\text { bituminosa }\end{array}$ & $\begin{array}{l}\text { aerial } \\
\text { parts }\end{array}$ & Algeria & $\begin{array}{l}\text { E- } \beta \text {-caryophyllene }(19.8 \%) \\
\text { caryophyllene oxide } \\
(15.2 \%) \\
\text { Z-phytol }(14.2 \%) \\
\text { E-phytol }(11.5 \%) \\
\beta \text {-copaene }(9.2 \%)\end{array}$ & $\begin{array}{l}\text { caryophyllene oxide }(35.5 \%) \\
\text { E-phytol }(25.6 \%) \\
T \text {-cadinol }(9.9 \%) \\
\alpha \text {-cadinol }(8.5 \%)\end{array}$ & [36] \\
\hline Rosa damascena & flowers & Turkey & $\begin{array}{l}\text { citronellol }(35.2 \%) \\
\text { geraniol }(22.2 \%) \\
\text { nonadecane }(13.9 \%) \\
\text { nerol }(10.3 \%)\end{array}$ & $\begin{array}{l}\text { geraniol }(30.7 \%) \\
\text { citronellol }(29.4 \%) \\
\text { phenylethyl alcohol }(23.7 \%) \\
\text { nerol }(16.1 \%)\end{array}$ & [37] \\
\hline Rosa damascena & flowers & Bulgaria & $\begin{array}{l}\text { citronellol }(31.5 \%) \\
\text { geraniol }(19.1 \%) \\
\text { nerol }(9.7 \%)\end{array}$ & $\begin{array}{l}\text { phenylethyl alcohol }(43.7 \%) \\
\text { citronellol }(18.2 \%) \\
\text { geraniol }(14.8 \%)\end{array}$ & [38] \\
\hline $\begin{array}{l}\text { Rosmarinus } \\
\text { officinalis }\end{array}$ & leaves & Japan & $\begin{array}{l}\text { eucalyptol }(18.9 \%) \\
\alpha \text {-pinene }(13.3 \%) \\
\text { camphor }(11.3 \%) \\
\beta \text {-pinene }(7.3 \%) \\
\text { borneol }(7.1 \%) \\
\text { bornyl acetate }(7.3 \%) \\
\beta \text {-myrcene }(5.6 \%)\end{array}$ & $\begin{array}{l}\text { camphor }(29.7 \%) \\
\text { borneol }(23.9 \%) \\
\text { eucalyptol }(20.5 \%)\end{array}$ & [39] \\
\hline $\begin{array}{l}\text { Rosmarinus } \\
\text { officinalis }\end{array}$ & flowers & Columbia & $\begin{array}{l}\text { camphor }(29.2 \%) \\
1,8 \text {-cineole }(21.1 \%) \\
\alpha \text {-pinene }(10.1 \%) \\
\text { camphene }(8.7 \%) \\
\beta \text {-pinene }(7.1 \%)\end{array}$ & $\begin{array}{l}\text { camphor }(51.9 \%) \\
1,8 \text {-cineole }(38.2 \%)\end{array}$ & [29] \\
\hline Salvia officinalis & $\begin{array}{l}\text { aerial } \\
\text { parts }\end{array}$ & Turkey & $\begin{array}{l}\text { 1,8-cineole }(17.9 \%) \\
\text { camphor }(19.9 \%) \\
\text { Z-thujone }(20.1 \%) \\
\text { E-thujone }(9.1 \%)\end{array}$ & $\begin{array}{l}\text { 1,8-cineole }(24.0 \%) \\
\text { camphor }(43.4 \%) \\
\text { Z-thujone }(15.5 \%) \\
\text { borneole }(7.7 \%)\end{array}$ & [9] \\
\hline Sideritis raeseri & $\begin{array}{l}\text { aerial } \\
\text { parts }\end{array}$ & Greece & $\begin{array}{l}\text { nucferol }(45.2 \%) \\
\text { spathulenol }(11.6 \%) \\
\text { caryophyllene oxide (5.6\%) }\end{array}$ & $\begin{array}{l}\text { carvacrol }(77.1 \%) \\
\text { nuciferol }(8.2 \%) \\
\text { a-bisabolol }(6.6 \%)\end{array}$ & [40] \\
\hline Solidago puberula & $\begin{array}{l}\text { aerial } \\
\text { parts }\end{array}$ & Canada & $\begin{array}{l}\alpha \text {-pinene }(37.2 \%) \\
\text { germacrene } \mathrm{D}(12.4 \%) \\
\text { limonene }(11.9 \%) \\
\text { myrcene }(11.1 \%)\end{array}$ & $\begin{array}{l}\text { benzyl alcohol }(73.3 \%) \\
\text { Z-3-hexen-1-ol }(7.7 \%)\end{array}$ & [13] \\
\hline Thymbra capitata & $\begin{array}{l}\text { aerial } \\
\text { parts }\end{array}$ & Greece & $\begin{array}{l}\gamma \text {-terpinene }(35.3 \%) \\
\text { p-cymene }(23 \%) \\
\text { carvacrol }(20.4 \%)\end{array}$ & carvacrol (946.3 $\left.\mathrm{mg} \mathrm{L}^{-1}\right)$ & [41] \\
\hline Thymus capitatus & $\begin{array}{l}\text { aerial } \\
\text { parts }\end{array}$ & Algeria & $\begin{array}{l}\text { carvacrol }(69.6 \%) \\
p \text {-cymene }(12.4 \%)\end{array}$ & carvacrol $(95.1 \%)$ & [42] \\
\hline Thymus capitatus & $\begin{array}{l}\text { aerial } \\
\text { parts }\end{array}$ & Italy & $\begin{array}{l}\text { carvacrol }(67.6 \%) \\
\beta \text {-caryophyllene }(7.7 \%) \\
\text {-terpinene }(6.8 \%) \\
\text { p-cymene }(6.4 \%)\end{array}$ & $\begin{array}{l}\text { carvacrol }(93.1 \%) \\
\text { thymol }(6.3 \%)\end{array}$ & [43] \\
\hline Thymus vulgaris & $\begin{array}{l}\text { aerial } \\
\text { parts }\end{array}$ & Columbia & $\begin{array}{l}\text { thymol }(36.1 \%) \\
p \text {-cymene }(28.4 \%) \\
\gamma \text {-terpinene }(11.6 \%)\end{array}$ & thymol $(98.1 \%)$ & [29] \\
\hline $\begin{array}{l}\text { Trachyspermum } \\
\text { ammi }\end{array}$ & seed & Iran & $\begin{array}{l}\text { thymol }(53.4 \%) \\
\text { o-cymene }(21.1 \%) \\
\text {-terpinene }(20.2 \%)\end{array}$ & $\begin{array}{l}\text { thymol }(90.9 \%) \\
\text { cuminic aldehyde }(6.4 \%)\end{array}$ & [18] \\
\hline Zataria multiflora & $\begin{array}{l}\text { aerial } \\
\text { parts }\end{array}$ & Iran & $\begin{array}{l}\text { thymol }(36.4 \%) \\
\text { carvacrol }(30.7 \%) \\
\text { o-cymene }(11.9 \%)\end{array}$ & $\begin{array}{l}\text { carvacrol }(55.9 \%) \\
\text { thymol }(40.4 \%)\end{array}$ & [18] \\
\hline
\end{tabular}

Hydrolates are acidic liquids $(\mathrm{pH}$ ranging from 4.5 to 5.5) with pleasant to unpleasant and from similar to dissimilar odor to the essential oil $[14,15]$. The quality of hydrolates is determined based on the amount of their soluble volatile compounds. For this reason, the absolute quantification is recommended in the quality control to ensure the optimum quality and to detect adulteration which is easily done by diluting hydrolates with water. Absolute quantification is also useful for providing the processor with full information about the potential application and safety of hydrolates [1]. The chemical composition of essential oils and corresponding hydrosols, according to literature are shown in Table 2.

The volatile components from hydrolates are mainly monoterpene alcohols, aldehydes and ketones, as well as sesquiterpene alcohols. They are highly polar (hydrophilic) compounds. However, hydrocarbon monoterpenes have very lower solubility in water at $\mathrm{pH}=7$ : less than $5 \mathrm{mg} \mathrm{L}^{-1}$ (they are lipophilic compounds). Because of this, they are not observed in the acidic hydrolates [7, 13]. In cases where the monoterpene hydrocarbons are dominant compounds in essential oils, the compositions of hydrolates are very different from the corresponding oils [12, 16]. However, if monoterpene hydrocarbons are present in hydrolates, their concentration is below the detection limit as only oxygenated compounds are observed [17].

Generally, the chemical structure of the component 
(polarity factor) determines the extent of hydrogen bonding with water molecules and hence its degree of solubility in water (at constant temperature) [1]. It appears that in some cases the composition of hydrolates at room temperature may change over a two-year period of storage. Possible hydratation processes may occur in the hydrolates during shelf-life [12]. In some cases, the main compounds of hydrolates are relatively stable in acidic water over the two-year observation period [13], while in another changes in the aroma and composition appear and on the intrinsic antimicrobial activity of the compounds contain [8].

As it is visible in Table 2, the similarity between the essential oil and the hydrolate composition depends mainly on the relation of hydrocarbons and oxygenated compounds in the essential oil. In materials in which oxygenated compounds are dominant in the essential oil, the degree of similarity between essential oil and hydrolate is very high. Inversely, when hydrocarbons are main essential oil constituents, hydrolate composition differs significantly from the essential oil composition.

A chemical composition of the essential oil depends on several factors e.g. place of geographical origin, habitat, the moment of harvesting, harvesting season, extraction methods, etc. Typically, the hydrolates include some of the water-soluble components of the essential oil along with other water-soluble plant secondary metabolites [44].

According to the data in Table 2, Mentha sp. essential oils are rich in oxygenated monoterpenes and are not rich in sesquiterpene. They contain small amounts of sesquiterpene hydrocarbons, which are absent in hydrolates as hydrocarbons not as sesquiterpenes. $M$. piperita and $M$. longifolia essential oils and hydrolates have very similar profiles. Economic importance is the feature of essential oils not mono- and sesquiterpenes $[1,13,16,18,30,31]$.

There are species with similar dominant compounds in essential oils and hydrolates such as E. caryophyllata with eugenol, $O$. basilicum with linalool, and $C$. citratus with geranial and neral [1]. Furthermore, the dominant compound in L. alba carvone [29], in S. officinalis 1,8-cineole [9] and in N. nepetella nepetalactones [33]. Leaves from different Eucalyptus sp. mainly contain 1,8-cineole as the dominant compound, both in essential oil and hydrolate $[22,23]$, while $E$. citrodora contain citronellal and citronellol in the essential oil, as well as in the hydrolate [1].

Several Rosmarinus officinalis chemotypes have been reported: a-pinene, cineole, p-cymene and camphor-limonene according to dominant compounds in the essential oil. Differences in the chemical composition may be caused by water solubility of aroma compounds. Camphor and borneol were found both in $R$. officinalis essential oils and hydrolates from Japan [39]. However, in the Columbian sample of $R$. officinalis, camphor and 1,8-cineole were dominant in both, essential oil and hydrolates [29]. These facts indicate the possibility of utilizing hydrolates for medicinal usage in the same purpose as essential oils [39].

In essential oil of $O$. vulgare, were dominated by hydrocarbons, followed by oxygenated compounds. However, hydrolates were dominated only by oxygenated compounds. These variations are observed due to relatively higher solubility of oxygenated compounds in water over the solubility of hydrocarbons. It can be said that the hydrolates of $O$. vulgare should not be discarded, as usually done by introducing cohobation system in the field distillation unit, in order to improve fresh herb and to minimize the loss of valuable components of the pure compounds (thymol and carvacrol). It can also be used as such for disinfection and cosmetic applications [5]. Furthermore, T. capitatus belongs to carvacrol chemotype [42, 43], while $T$. vulgaris belongs to thymol chemotype [29], it is visible in the essential oil, as well as in the hydrolate composition. This confirmed the possibility of using thyme and oregano hydrolates as antimicrobial agents similarly to their essential oils [45].

Lavender ( $L$. angustifolia) and lavandin ( $L$. intermedia) have the same composition but in different proportions. However, hydrolates of both species have linalool as the dominant compound, but they did not contain any linalyl acetate. This can be explained by the fact that linalool is water soluble while linalyl acetate is insoluble in water [27]. Similarly, both essential oil and hydrolate of $C$. aurantium contain linalool and linalyl acetate as the dominant compounds. However, in different proportions [1].

Citronellol and geraniol were the major compounds of $R$. damascena hydrolate and the essential oil [37]. Piperitone was found in all samples of $P$. chimonanthifolium. This monoterpene is the major compound in all hydrolates and in the essential oils of the stem and leaf, and the second most abundant compound in the essential oil of inflorescence [35]. In case of C. subhirtella and C. serrulata benzaldehyde was the key component of the essential oils, while benzaldehyde, as well as mandelonitrile was the principal compound of hydrolates [19].

Apart from this, there are some species with completely different composition of essential oils and hydrolates (Table 2), such as Abies sp., A. canadense, C. peregrina, D. carota subsp. sativus, L. porteri, M. officinalis, M. gale, Picea sp., Psoralea bituminosa, Sideritis raeseri and S. puberula $[7,10,11,12,13,17,21,34,36,40]$.

\section{Biological activity}

The biological activity of hydrolates depends on the presence of components that characterize them with their functional groups [8]. The knowledge of the chemotype of the plant material used for the essential oil extraction, as well as hydrosol is of fundamental importance to understand the mechanisms of its biological activity. However, the investigation of hydrolates biological activity is focused mainly on antimicrobial, antioxidant and antiinflamatory activity. 
Table 3. Antimicrobial activity of hydrolates (inhibition zone diameter in $\mathrm{mm}$ )

\begin{tabular}{|c|c|c|c|c|c|c|c|c|c|c|c|c|c|c|c|c|c|c|c|}
\hline $\begin{array}{l}\frac{0}{0} \\
\frac{\pi}{0} \\
\frac{0}{0} \\
0 \\
\frac{\pi}{0} \\
\frac{\pi}{\alpha}\end{array}$ & 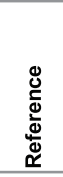 & 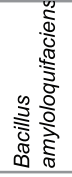 & 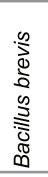 & 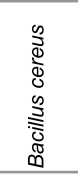 & 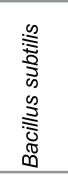 & 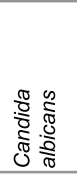 & 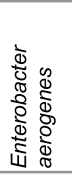 & 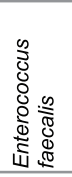 & 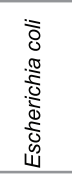 & 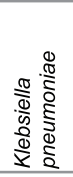 & 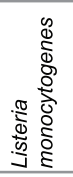 & 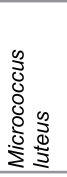 & 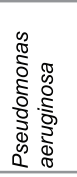 & 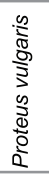 & 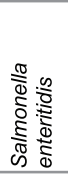 & 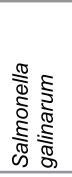 & 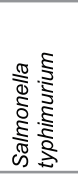 & 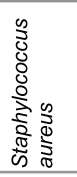 & 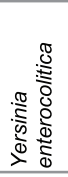 \\
\hline Alium tuberosum & [46] & & & & 30 & & & & & & & & & & 25 & & & & \\
\hline $\begin{array}{l}\text { Areca catechu (floral } \\
\text { axis) }\end{array}$ & {$[47]$} & & & & & 11.6 & & & $\begin{array}{l}12.6 / \\
9.9^{*}\end{array}$ & & & & & & & & & 12.9 & \\
\hline Nepeta nepetella & {$[33]$} & & & 18.0 & 16.0 & $\begin{array}{l}32.0 / \\
37.0^{\star}\end{array}$ & & 12.0 & 9.0 & 7.0 & 10.0 & & 7.0 & & & & & 18.0 & \\
\hline $\begin{array}{l}\text { Areca catechu } \\
\text { (flowers) }\end{array}$ & [47] & & & & & 12.1 & & & $\begin{array}{l}11.2 / \\
10.2^{*}\end{array}$ & & & & & & & & & 12.7 & \\
\hline Areca catechu (root) & {$[47]$} & & & & & 10.3 & & & $\begin{array}{c}9.8 / 8 \\
5^{\star}\end{array}$ & & & & & & & & & 11.7 & \\
\hline $\begin{array}{l}\text { Citrus aurantifolia } \\
\text { (fresh peels) }\end{array}$ & [48] & & & & 4 & 2 & & 1 & 4 & & & & & & & & & 5 & \\
\hline $\begin{array}{l}\text { Citrus citratus (dried } \\
\text { leaves) }\end{array}$ & [46] & & & & 6 & 2 & & - & 3 & & & & & & & & & 3 & \\
\hline $\begin{array}{l}\text { Citrus odorata (fresh } \\
\text { leaves) }\end{array}$ & {$[47]$} & & & & 3 & - & & - & - & & & & & & & & & 1 & \\
\hline $\begin{array}{l}\text { Cocos nucifera } \\
\text { (floral axis) }\end{array}$ & {$[47]$} & & & & & 14.0 & & & $\begin{array}{l}11.7 / \\
6.9^{*}\end{array}$ & & & & & & & & & 11.3 & \\
\hline $\begin{array}{l}\text { Cocos nucifera } \\
\text { (flowers) }\end{array}$ & [45] & & & & & 14.2 & & & $\begin{array}{l}13.8 / \\
6.8^{*}\end{array}$ & & & & & & & & & 12.3 & \\
\hline Cocos nucifera (root) & {$[45]$} & & & & & 12.5 & & & $\begin{array}{l}12.5 / \\
7.4^{*}\end{array}$ & & & & & & & & & 7.2 & \\
\hline Cuminum cyminum & [48] & - & 14 & - & - & & 26 & & $-/ 19^{*}$ & - & & & & - & - & - & - & - & - \\
\hline Lantana camara & [45] & & & $-\overline{16 / 10 *}$ & & & & & - & & & $\begin{array}{l}9 / 10 / \\
11 *\end{array}$ & & & & & & $\begin{array}{l}5 / 6 / 7 \\
\quad *\end{array}$ & \\
\hline Mentha piperita & [48] & & & & 13 & & & & & & & & & & 12 & & & & \\
\hline $\begin{array}{l}\text { Ocimum gratissimum } \\
\text { (dried leaves) }\end{array}$ & {$[46]$} & & & & - & 1 & & 1 & 2 & & & & & & & & & 1 & \\
\hline $\begin{array}{l}\text { Ocimum gratissimum } \\
\text { (fresh leaves) }\end{array}$ & {$[46]$} & & & & 2 & 1.5 & & - & 2 & & & & & & & & & 2 & \\
\hline Origanum majorana & [48] & & & & & & & & $\underset{*}{19 / 18}$ & & & & & & & & & 22 & 18 \\
\hline Origanum onoites & [48] & & & & & & & & $\underset{*}{17 / 19}$ & & & & & & & & & 30 & 16 \\
\hline Origanum vulgare & [46] & 27 & 15 & 14 & 20 & & 14 & & $\underset{*}{16 / 19}$ & 20 & & & & 19 & 15 & 14 & 20 & $\underset{*}{33 / 15}$ & 16 \\
\hline Origanum vulgare & [45] & & & & & & & & $\underset{*}{13 / 15}$ & & & & & & & & & 21 & 12 \\
\hline Pimpinella anisum & [45] & - & - & - & - & & - & & $9 /$-* $^{*}$ & - & & & & - & - & - & - & $-/ 12^{*}$ & - \\
\hline Piper nigrum & [46] & & & & 10 & & & & & & & & & & 11 & & & & \\
\hline Salvia fructicosa & [47] & & & & 15 & & & & & & & & & & 13 & & & & \\
\hline Satureja hortensis & [47] & 14 & 15 & 15 & 14 & & 16 & & $\underset{*}{18 / 10}$ & 16 & & & & 16 & 17 & 16 & 15 & $\underset{*}{18 / 16}$ & 17 \\
\hline Thymbra spicata & [47] & 12 & 16 & 15 & - & & - & & $13 /$-* $^{*}$ & - & & & & 14 & 14 & 14 & - & $-/ 10^{*}$ & 13 \\
\hline Thymbra spicata & [48] & & & & 20 & & & & & & & & & & 15 & & & & \\
\hline Thymus serpyllum & [46] & & & & & & & & $\underset{*}{14 / 12}$ & & & & & & & & & 18 & 14 \\
\hline Thymus vulgaris & [47] & & & & & & & & $\underset{*}{14 / 12}$ & & & & & & & & & 17 & 13 \\
\hline
\end{tabular}

Antimicrobial activity

The effectiveness of hydrolates as natural antimicrobials depends on the absolute quantity of their major soluble aromatics [1]. However, antimicrobial potential in vitro was tested using a paper disk diffusion method. Data about antibacterial and antifungal activities of hydrolates (values are expressed as inhibition zone in $\mathrm{mm}$ ) is shown in Table 3. Furthermore, some results showed that hydrolates possess a strong antifungal activity based on the inhibition zone, minimal inhibitory concentration or minimal fungicidal concentration against Candida albicans, and phytopathogenic and toxic fungi (Table 4).

Antimicrobial properties of hydrolates depend on the microbial strain and concentration, i.e. dilution [30,33, 38, 45]. Despite a higher concentration needed for the same inhibitory effect, the amount of terpenes supplied with hydrolate was lower than in the essential oil. This means a higher hydro- late effectiveness that is likely to occur due to the hydrophilic environment promoting a higher terpene availability. Lastly, hydrolate exhibited promising results in the control of fungal growth on paper artwork, suppressing the four tested strains at concentrations of $25-50 \%$ [32]. The plant part [51] or date of harvest [20], processing plant material (fresh or dry) [47], as well as the extraction method [20], or formulations such as nanoemulsion [28], also influence the chemical composition and further antimicrobial properties. Apart from this, it is established that hydrolate exhibited considerable antibacterial activities against the Gram-positive bacteria, while Gram negative bacteria were found to be resistant. This is most probably due to its outer membrane $[43,52]$. Furthermore, only $L$. intermedia hydrolate formulated in nanoemulsion exhibited activity against $E$. coli (MIC value was $0.75 \%$ ) and $B$. cereus (MIC value $0.60 \%$ ), whereas pure hydrolate was inactive on both bacteria strains [28]. 
Table 4. Antifungal activity based on the minimal inhibitory concentration - MIC $\left(\mu \mathrm{gL}^{-1}\right)$

\begin{tabular}{|c|c|c|c|c|c|c|c|c|c|c|c|c|}
\hline 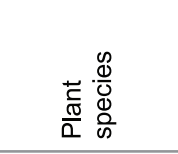 & 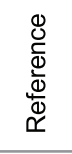 & 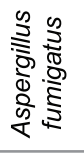 & 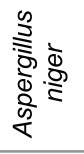 & 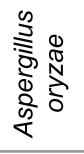 & 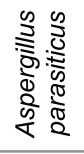 & 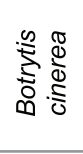 & 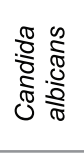 & 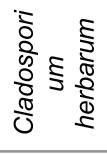 & 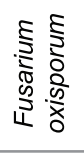 & 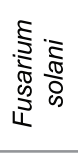 & 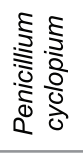 & 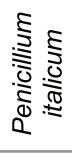 \\
\hline $\begin{array}{l}\text { Anthemis } \\
\text { nobile }\end{array}$ & [49] & & & & & & $>800$ & & & & & \\
\hline $\begin{array}{l}\text { Citrus } \\
\text { aurantium }\end{array}$ & [49] & & & & & & 1600 & & & & & \\
\hline $\begin{array}{l}\text { Cymbopogon } \\
\text { citratus }\end{array}$ & [49] & & & & & & 400 & & & & & \\
\hline $\begin{array}{l}\text { Eugenia } \\
\text { caryophyllata }\end{array}$ & [49] & & & & & & 400 & & & & & \\
\hline $\begin{array}{l}\text { Eupatorium } \\
\text { japonicum }\end{array}$ & [49] & & & & & & $>800$ & & & & & \\
\hline $\begin{array}{l}\text { Eupatorium } \\
\text { laciniatum }\end{array}$ & [49] & & & & & & $>800$ & & & & & \\
\hline $\begin{array}{l}\text { Lavandula } \\
\text { angustifolia }\end{array}$ & [49] & & & & & & 3200 & & & & & \\
\hline $\begin{array}{l}\text { Lindera } \\
\text { umbellate }\end{array}$ & [49] & & & & & & 800 & & & & & \\
\hline $\begin{array}{l}\text { Matricaria } \\
\text { recutita }\end{array}$ & [49] & & & & & & $>800$ & & & & & \\
\hline Mentha crispa & [50] & 2.5 & & & 5.0 & $<0.32$ & & 0.32 & 5.0 & & 2.5 & \\
\hline $\begin{array}{l}\text { Monarda } \\
\text { fistulosa }\end{array}$ & [49] & & & & & & 50 & & & & & \\
\hline $\begin{array}{l}\text { Pelargonium } \\
\text { asperum }\end{array}$ & [49] & & & & & & $>800$ & & & & & \\
\hline $\begin{array}{l}\text { Tanacetum } \\
\text { vulgare }\end{array}$ & [49] & & & & & & $>800$ & & & & & \\
\hline $\begin{array}{l}\text { Thymus } \\
\text { capitatus }\end{array}$ & [42] & & 0.5 & 0.2 & & & & & & 0.2 & & 0.1 \\
\hline
\end{tabular}

Investigations of Thymus capitatus hydrolate against Salmonella enterica show that this plant hydrolate possesses a significant antimicrobial action against both planktonic and biofilms cells of a common foodborne pathogen. The advantages of using hydrolates to disinfect food-contact surfaces are numerous. It is an aqueous solution which can easily be rinsed out from surfaces, it does not have the strong smell of the essential oil and it is a by-product of the essential oil distillation procedure. Consequently, hydrolates could obviously be of great value to combat biofilms and thus improve product safety not only for the food industries but also for many other industries which experience biofilms-related problems [41].

Thymus thymbra hydrolate exhibits sufficient bactericidal effects on bacterial biofilms of Staphylococcus simulans, Lactobacillus fermentum, Pseudomonas putida, Salmonella enterica and Listeria monocytogenes that formed on stainless steel. Use of natural antimicrobial agents could provide alternative or supplemented ways for disinfecting microbial-contaminated industrial surfaces [53].

These results suggest that the use of some spice hydrolates as antimicrobial agents may be exploitable to prevent the deterioration of stored foods by bacteria, as long as the taste impact is acceptable in the targeted foods [48]. According to this, hydrolates are considered natural food and feed additives to improve gut health in humans and animals [46].

Apart from antifungal and antibacterial activities, the antiviral activity assay indicated that Thymus vulgaris and Nepeta cataria hydrolates reduced the porcine reproductive and respiratory syndrome load in vitro significantly. Moreover, the mechanisms of action for both $T$. vulgaris and $N$. cataria hydrolates were in both pre-entry and post-entry steps. These results suggest that both hydrolates have therapeutic potential in the prophylaxis and the treatment of porcine reproductive and respiratory syndrome infection [54].

Antioxidant activity

Hydrolates produced from Hyssopus officinalis, Marrubium vulgare and Artemisia herba-alba originating from Morocco expressed a good antioxidant activity [14]. Gaharu hydrolate which is produced during the hydrodistillation of resinous wood part of Aquilaria sp. exhibited very low antioxidant activity in comparison to quercetin [55].

Thymus vulgaris hydrolate possesses a high antioxidant activity in comparison to synthetic or natural antioxidant used in the formulation of a cosmetic or phytopharmaceutical product, if it is used as therapeutic active principle, it could also allow the preservation of the product with its antioxidant efficacy [29]. Furthermore, the Syzygium aromaticum and Thymus vulgaris hydrolates, predominantly consisting of eugenol and carvacrol, respectively, were the most effective as antioxidants for the prevention of lipid peroxidation through the measurement of malonaldehyde produced after degradation of hydroperoxides. In case of scavenging superoxide anion radical Lavandula officinalis hydrolate in which linalool prevailed was a stronger antioxidant [56].

The iron reduction assay and free radical scavenging 
capacity were used for antioxidant evaluation of Poliomintha longiflora essential oil, hydrolate and solid waste residues. The essential oil presented the highest biological activities for antioxidant and antimicrobial tests while the hydrolate and the solid waste residues had the lowest antioxidant activity and the hydrolate had the lowest antimicrobial activity. However, the data suggests that $P$. longiflora hydrolate and extracts from solid waste residues can still have compounds with antimicrobial and antioxidant capacities [57].

\section{Antiinflamatory properties}

Depending on the method of evaluation of the antioxidant activity, the essential oils and hydrolates showed different results. Independently of the method used, the hydrolates exhibited a lower antioxidant activity than the respective essential oils [20].

Study with Tetragonia tetragonoides hydrolate showed that the treatment with this hydrolate inhibited the lipopolysaccharide (LPS)-induced nitric oxide (NO) and prostaglandin E2 (PGE2) production in RAW 264.7 cells by suppressing inducible NO synthase (iNOS) and cyclooxygenase-2 (COX-2) expression, respectively. $T$. tetragonoides hydrolates also inhibited the LPS-induced production of interleukin (IL)-1 $\beta$ and IL-6 in RAW 264.7 cells. These effects could have been exerted by the inhibition of nuclear factor-kappa B (NF-kB) activation and phosphorylation of the mitogen-activated protein kinases (MAPK) pathways. These findings provide evidence that $T$. tetragonoides hydrolates exhibits potential antiinflammatory activities [58].

Rosa damascene hydrolate suppressed neutrophil activation induced by lipopolysaccharide (LPS), tumor necrosis factor alpha (TNF- $\alpha$ ), and N-formyl-Met-LeuPhe (fMLP) at $5-15 \%$. It also reduced the LPS- and TNF-a-induced cell surface expression of the adhesionrelated molecule. However, it did not affect the migratory capacity of neutrophils with or without chemoattractant. These results suggest that rose water may reduce the pathogenicity of microbes, and attenuate neutrophil stimulation, which is involved in inflammatory responses. These findings suggest that rose water has a potential effect to inhibit skin inflammation caused by microbes [38].

A pilot study aimed to investigate the preventive effect of Salvia officinalis, Thymus vulgaris and Mentha piperita hydrolates oral rinse used in conjunction with basic oral care on chemotherapy-induced oral mucositis show that these hydrolates show promising results in alleviating oral mucositis, and due to this, hydrolates can be recommended for clinical use as they are well tolerated and cost effective [59].

\section{Application}

Due to the increased interest for natural products, it is important to understand biological activities for developing new applications in food, human health, and agriculture against insects and pests. Biological and organoleptic properties of hydrolates make them useful. Typically, in commercial production, essential oils are skimmed off and the hydrolate is discarded as waste. But they can be cohobated back to the source solution, and in that way reduce the waste and environmental pollution. They could also be further extracted with another lipophilic solvent to obtain the secondary oil in opposition to the primary one that naturally evaporates during distillation. Hydrolates have a much softer scent and are less biologically active than corresponding essential oils. Blending the primary and the recovered oil from hydrolates gave more richness and fullness to the oil $[5,25,34]$.

However, according to the research results, hydrolates had great potential for usage in food industry in drinks, for flavoring fruit beverages, confectioneries and soft drinks, and for food preservation, and as a convenient sanitizing agent while washing fresh-cut fruits and vegetables. Apart from this, they can be used for sanitizing other food products such as freshwater fish, fermented meat products (sausage and suck), as well as for disinfection of food and areas in contact with it. Furthermore, hydrolates are often used in cosmetics and perfume industry, as well as in aromatherapy.

\section{Functional (soft) drinks}

Traditionally hydrolates are used as drinks and in food products [4]. For example, sage hydrolate is released from a by-product during the distillation in Turkey and is drunk as a natural antibiotic against various bacterial diseases and digestion disorders [9]. Furthermore, in traditional and folk Persian medicine, hydrolates are used as drinks for medicinal purposes to treat different conditions [60, 61]. For example, fennel hydrolate was suggested to start menstruation while yarrow aromatic water to regulate menstruation. These hydrolate are used for women's reproductive and hormonal health. However, scientific investigation of these hydrolates may lead to the development of some functional beverages and soft drinks as a safe use of essential oils or even new lead components or therapeutic agents [3]. Furthermore, Trachyspermum ammi are traditional Persian medicines applied for chronic pain and neural ailments such as tremor, paralysis, and palsy. As a by-product T. ammi hydrolate can be considered as an almost pure, but inexpensive and easy producible resource of natural thymol (84.33-95.62\%). In accordance with the pharmacological properties of thymol, this preparation can be applied in numerous relevant clinical and phytopharmaceutical approaches [15]. The hydrolate of Citrus aurantium flowers, commonly known as neroli, has been used in traditional medicine as a remedy for the treatment of mild depression, sedation and as a heart tonic [62], while Lavandula angustifolia hydrolates exhibit revitalizing and relaxing properties when consumed in the form of an additive to water or food [63].

Biopreservation of fresh-cut fruits and vegetables

(natural food sanitizers)

Investigations have shown that an abundance of fresh fruit and vegetables that are rich in minerals, vitamins and 
phytochemicals in a diet promotes a healthy life and decreases the risk of diseases. However, water washing is not effective itself for extending the shelf life of the product by decontamination. Therefore, several sanitizers are used in fresh-cut industry. Chlorine based chemicals are the most common sanitizers with their low cost and proven effectiveness against pathogens. However, nowadays, consumers demand more natural processing of fresh-cut fruit and vegetables. Up to date, a number of physical and chemical fresh-cut sanitization methods have been tested in order to eliminate the use of chlorine from fresh-cut industry, decrease high water requirement, as well as provide high decontamination efficiency [64]. However, investigations show that hydrolates inhibit tyrosinase - the main enzyme responsible for the browning reaction of fruits and vegetables, at varying levels depending on substrate type and concentration $[65,66]$.

Since fresh or minimally processed fruits and vegetables are established as a source of several outbreaks caused by Escherichia coli and Staphylococcus, strategies based on natural preservatives are being developed to control and decontaminate. The simple and inexpensive production method of hydrolates and their recognition for safe human consumption also focused on these compounds as antimicrobial components [67]. For these reasons, there are many studies with hydrolate treatment of fresh-cut fruits (apple) and vegetables (iceberg lettuce, carrots, tomato, parsley and cucumbers).

Rosmarinus officinalis and Thymus vulgaris hydrolates were found to be the most efficient sanitizers in reducing the Staphylococcus aureus numbers. Results demonstrate that predictive models could be utilized for describing the inactivation or survival of $S$. aureus on fresh-cut apple with the effects of the treatments with plant hydrolates [68].

Inhibitory effects of the hydrolates of Thymus vulgaris, Nigella sativa, Rosmarinus officinalis, Salvia officinalis and Laurus nobilis were investigated against Salmonella Typhimurium and Escherichia coli inoculated into apple and carrots. T. vulgaris showed the highest antibacterial effects on both S. Typhimurium and E. coli. L. nobilis hydrolate significantly reduced $E$. coli population on apple and carrot samples. In conclusion, it was shown that plant hydrolates, especially $T$. vulgaris hydrolate, could be used as a convenient sanitizing agent during the washing of fresh-cut fruits and vegetables [69].

Hydrolates from Thymus vulgaris, Satureja hortensis and Origanum onites were evaluated for their antibacterial activity against $E$. coli inoculated into fresh-cut tomato and cucumbers. The results suggested that hydrolates from these plants have the potential to be used as natural food sanitizers for fresh cut tomatoes and cucumbers to provide their microbial safety without causing any sensorial defect on treated products or health problems in humans [70].

Table 5: Antibacterial activity of the plant hydrolates on the bacterial strains depend on treatment time (20, 40 and $60 \mathrm{~min}) \log 10 \mathrm{cfu} \mathrm{g}^{-1}$

\begin{tabular}{|c|c|c|c|c|c|c|c|c|c|c|c|}
\hline \multirow{3}{*}{$\begin{array}{l}\text { Plant } \\
\text { material } \\
\text { Laurus } \\
\text { nobilis }\end{array}$} & \multirow{2}{*}{$\begin{array}{l}\text { Treated } \\
\text { plant }\end{array}$} & \multirow{2}{*}{ Reference } & \multicolumn{2}{|c|}{ Escherichia coli } & \multirow[b]{2}{*}{60} & \multicolumn{3}{|c|}{ Listeria monocitogenes } & \multicolumn{3}{|c|}{ Salmonela Typhimurium } \\
\hline & & & 20 & 40 & & 20 & 40 & 60 & 20 & 40 & 60 \\
\hline & $\begin{array}{l}\text { lceberg } \\
\text { lettuce }\end{array}$ & {$[64]$} & 4.99 & 4.95 & 4.84 & 4.89 & 4.69 & 4.57 & 6.46 & 6.10 & 6.05 \\
\hline $\begin{array}{l}\text { Laurus } \\
\text { nobilis }\end{array}$ & Apple & [69] & 5.20 & 4.97 & 4.80 & & & & 5.15 & 5.01 & 5.00 \\
\hline $\begin{array}{l}\text { Laurus } \\
\text { nobilis }\end{array}$ & Carrot & [69] & 4.65 & 4.67 & 4.51 & & & & 5.68 & 5.51 & 5.39 \\
\hline $\begin{array}{l}\text { Nigella } \\
\text { sativa }\end{array}$ & Apple & [69] & 5.15 & 5.01 & 4.97 & & & & 5.04 & 5.04 & 5.06 \\
\hline $\begin{array}{l}\text { Nigella } \\
\text { sativa }\end{array}$ & Carrot & [69] & 4.60 & 4.53 & 4.47 & & & & 5.61 & 5.57 & 5.30 \\
\hline $\begin{array}{l}\text { Origanum } \\
\text { onoites }\end{array}$ & $\begin{array}{l}\text { lceberg } \\
\text { lettuce }\end{array}$ & [64] & 3.86 & 3.74 & 3.70 & 3.73 & 3.30 & 2.89 & 4.29 & 4.07 & 3.60 \\
\hline $\begin{array}{l}\text { Rosmarinus } \\
\text { officinalis }\end{array}$ & $\begin{array}{l}\text { Iceberg } \\
\text { lettuce }\end{array}$ & [64] & 4.95 & 4.13 & 4.01 & 4.89 & 4.69 & 4.53 & 6.02 & 5.85 & 5.23 \\
\hline $\begin{array}{l}\text { Rosmarinus } \\
\text { officinalis }\end{array}$ & Apple & [69] & 4.57 & 4.49 & 4.35 & & & & 5.09 & 4.97 & 4.77 \\
\hline $\begin{array}{l}\text { Rosmarinus } \\
\text { officinalis }\end{array}$ & Carrot & [69] & 4.59 & 4.58 & 4.51 & & & & 5.64 & 5.67 & 5.37 \\
\hline $\begin{array}{l}\text { Salvia } \\
\text { officinalis }\end{array}$ & $\begin{array}{l}\text { lceberg } \\
\text { lettuce }\end{array}$ & [64] & 5.18 & 4.99 & 4.69 & 4.54 & 4.60 & 4.25 & 6.30 & 6.26 & 6.15 \\
\hline $\begin{array}{l}\text { Salvia } \\
\text { officinalis }\end{array}$ & Apple & [69] & 4.82 & 4.75 & 4.73 & & & & 5.14 & 5.10 & 4.93 \\
\hline $\begin{array}{l}\text { Salvia } \\
\text { officinalis }\end{array}$ & Carrot & [69] & 4.62 & 4.63 & 4.53 & & & & 5.64 & 5.44 & 5.16 \\
\hline $\begin{array}{l}\text { Satureja } \\
\text { hortensis }\end{array}$ & $\begin{array}{l}\text { lceberg } \\
\text { lettuce }\end{array}$ & [64] & 3.75 & 2.75 & 2.45 & 3.84 & 3.11 & 2.84 & 3.99 & 4.04 & 3.94 \\
\hline $\begin{array}{l}\text { Sideritis } \\
\text { canariensis }\end{array}$ & $\begin{array}{l}\text { lceberg } \\
\text { lettuce }\end{array}$ & [64] & 5.30 & 4.69 & 4.45 & 4.69 & 4.60 & 3.52 & 6.15 & 6.11 & 6.01 \\
\hline $\begin{array}{l}\text { Thymus } \\
\text { vulgaris }\end{array}$ & $\begin{array}{l}\text { Iceberg } \\
\text { lettuce }\end{array}$ & [64] & 3.96 & 3.47 & 2.99 & 3.75 & 3.30 & 2.54 & 4.57 & 4.04 & 3.74 \\
\hline $\begin{array}{l}\text { Thymus } \\
\text { vulgaris }\end{array}$ & Apple & [69] & 4.48 & 4.44 & 4.44 & & & & 4.81 & 4.81 & 4.73 \\
\hline $\begin{array}{l}\text { Thymus } \\
\text { vulgaris }\end{array}$ & Carrot & [69] & 4.73 & 4.58 & 4.37 & & & & 4.82 & 4.40 & 4.32 \\
\hline
\end{tabular}


The inhibitory effects of Salvia officinalis, Rosmarinus officinalis, Origanum vulgare and Thymus vulgaris hydrolates were evaluated against Escherichia coli and Staphylococcus aureus inoculated into parsley at high and low concentrations. Following the pathogen inoculations, parsley samples were washed with hydrolates, and the reduction of pathogen counts were determined. Decontamination of foodborne pathogens from fresh-cut vegetables can be achieved by hydrolate treatments [67].

Six hydrolates (T. vulgaris, $S$. hortensis, $R$. officinalis, $S$. officinalis, Sideritis canariensis, Origanum onites and Laurus nobilis) were used for decontamination of freshcut iceberg lettuce inoculated with Salmonella enterica, Listeria monocytogenes and Escherichia coli. Thymus vulgaris and S. hortensis hydrolates archived the reduction of all bacterial strains. Hydrolate treated samples, especially with $L$. nobilis and $S$. canariensis, were generally accepted by the panellist. This study confirmed that plant hydrolates could be successfully used for sanitizing fresh-cut lettuce to provide their microbiological safety without causing deep sensorial defects of the products [64].

The application of different hydrolates depends on the treatment time. However, hydrolates used in biopreservation of fresh-cut fruits (apple) and vegetables (iceberg lettuce and carrot) depend on time (20, 40 and $60 \mathrm{~min}$ ) are summarized in Table 5. Values are expressed as log $10 \mathrm{cfu} \mathrm{g}^{-1}$.

\section{Biopreservation of other food products}

The in vitro antibacterial activity of the Thymus serpyllum and Syzygium aromaticum hydrolates were tested against Aeromonas hydrophila, Escherichia coli, Pseudomonas aeruginosa and Pseudomonas fluorescens which are responsible for the spoilage of freshwater fish. It is found that these hydrolates were effective against all bacteria. Consequently, it is likely that these plant hydrolates may be used as antimicrobial agents to prevent the deterioration of food products [71].

Antifungal agent Thymus vulgaris hydrolate was applied to a fermented sausage and suck surface mycobiota was tested. However, T. vulgaris hydrolate did not affect the number of lactic acid bacteria and Mycrococcaceae which are important microorganism groups for properties such as taste, aroma and color of fermented sausage. In future studies, hydrolates should be tested at different concentrations against specific mold or yeast species which are undesirable on the surface of fermented sausage and suck [72].

Hydrolates meet the requirements to be used as natural antimicrobials in food industry, also as sanitizing solutions for tools, machines and working surfaces. In fact, being aqueous solutions, the hydrolates could be easily rinsed out from surfaces, and do not have a strong persistant smell, contrarily to essential oils. Moreover, hydrolates may provide valuable alternative pathways for the prevention of biofilms formation on working tools and surfaces [8]. Lippa palmeri hydrolate has an antibacterial activity against Listeria monocytogenes, exhibiting a concentration-response type of relationship. It could be used as an active ingredient in the disinfection of food and areas in contact with it [73].

Nowadays, people wish to consume value added products as a part of their everyday meal. The addition of Cymbopogon citratus hydrolate in the concentration of $3.5 \%$ leads to the production of new naturally flavored herbal ice-cream [74]. Furthermore, increased environmental concerns about synthetic packaging have promoted the development of novel, environmentally friendly edible biofilms. Coating eggs with pectin and Cinnamomum verum hydrosol led to lower weight loss during storage, better structural homogeneity and microbial quality during storage time during a six-week period [75].

\section{Aromatherapy and cosmetics}

Hydrolate therapy has been evolved as a complementary alternative medicinal modality, with the current resurgence of interest in aromatherapy [44,76]. Hydrolates, as water solutions, are extensively used because they can be easily applied topically without dilution $[63,65]$. They can be used as facial and body sprays mainly to feel cool and refreshed. Apart from this, the investigations conducted with Cinnamon zeylanicum hydrolate show that it has the effect on coagulation, useful in the situation when the wound is not clotting [77].

Depending on aromatic intensity of the hydrosol used, they can prevent body odor, especially if they possess antimicrobial properties, appropriately helpful in minimizing foot odor. Furthermore, they can help to ease itching caused by dry skin and dandruff, as well as wound healing. Apart from this, they are helpful with insect bites, but they also act as insect repellents. In addition, when hydrolates are used in skin care or as massage products, it is important to ensure that the amount of the soluble aromatics is not big enough to cause skin sensitivity [1].

Hydrolates are increasingly replacing water in cosmetics, providing additional active ingredients. Hydrolates are used as the aqueous phase in the production of lotions, creams and soaps, or independently as tonics and air fresheners. The application of hydrolates as raw material in the cosmetic industry results in both reducing expenses for sewage disposal and environmental burden as they are no longer discarded to the environment. Lavender hydrolate used as a replacement for water phase in cosmetics may contribute to maintaining microbiological stability of cosmetic formulations. Furthermore, lavender hydrolate can be directly applied on every type of skin, particularly the impure and oily. It experts cooling, hydrating toning action similar to oil, and it alleviates mental fatigue and stress states $[63,65]$.

Apart from all this, hydrolates are often used as air freshening sprays, due to their therapeutic properties, to reduce stress and anxiety, to help induce a sense of calm. They are also used to help purify and cleanse the living area. They find their application in fragrance sheets, towels and linen, as well as clothes, to eliminate 
unpleasant musty, smoky or other odors. They are also used for car fresheners.

\section{Organic agriculture}

Using the chemical substances in weed control, diseases and pests, without discernment has been responsible for the environmental damage and human health. For these reasons, in the last years the research has intensified its efforts to find alternative agriculture strategies [78]. Furthermore, post-harvest loses, particularly due to fungal invasions, are much more significant for highly perishable fresh fruits and vegetables than field crops. The use of synthetic chemicals to control post-harvest deterioration of food commodities is restricted, due to their possible carcinogenicity, teratogenicity, high and acute toxicity, long degradation periods, environmental pollution and their effects on human beings. Therefore, alternatives to synthetic pesticides are needed from microbial and plant sources [79].

The investigation of antifungal activity of Ocimum basilicum, Cuminum cyminum, Echinophora tenuifolia, Rosmarinus officinalis and Satureja hortensis against some plant pathogen fungi (Rhizoctonia solani, Fusarium oxysporum f. sp. tulipae, Botrytis cinerea and Alternaria citri) in vitro shows that $C$. cyminum, S. hortensis and E. tenuifolia. Furthermore, the hydrolate of Satureja hortensis showed a fungicidal effect against Alternaria mali, Sclerotinia sclerotiorum and Colletotrichum citrcinans. These results may contribute to the development of environmentally safe alternatives to synthetic preservatives to protect spoilage of food products from pathogenic and saprophytic fungi [79, 80,81].

Citrus sinensis fruits infected by $P$. italicum were treated in vivo with hydrolates. It was established that $0.2 \mu \mathrm{g} \mathrm{mL}^{-1}$ of $T$. capitatus hydrolate was enough to result in the absence of orange infection and causing $100 \%$ mycelial growth inhibition. This activity can be correlated with the chemical composition of extracts which are rich in carvacrol (more than 69\%). Therefore, the preventive and curative effects of $T$. capitatus essential oil and its hydrolate could be exploited as an ideal alternative to synthetic fungicides for treating many fungal phytopathogens causing severe destruction to oranges [42].

The hydrolate of Daucus carota subsp. sativus roots showed the best inhibition effect against Penicillium expansum and Botrytis cinerea. The results showed that the treatments of strawberry fruit with roots essential oil and hydrolate extract of $D$. carota subsp. sativus presented a very interesting protective and preventive activity on the strawberry against $B$. cinerea mold. They prove to be valuable raw material not only for cosmetic industries but also for post-harvest treatment. They can be used for the development of new and effective methods, which are regarded as safe and eco-friendly to control post-harvest diseases [21].

Apart from potential application as an antifungal agent, the investigations are focused also on insecticidal, as well as nematocidal activity of hydrolates and the possibilities for their use in organic agriculture both in the field production and during storage. The results of investigations on the influence of Mentha pulegium and $M$. suaveolens hydrolates on insect pest of citrus Taxopera aurantii have shown a high insecticidal effect, and that $M$. suaveolens hydrolate is more effective against citrus pests than $M$. pulegium. Consequently, these natural compounds can be used in the management of aphids on citrus [76]. Furthermore, hydrosols of Mentha pulegium and Melissa officinalis had the strongest inhibitory effect against Myzus persicae, while Origanum majorana caused $10-15 \%$ aphid mortality. These results clearly showed that potential of hydrosols in pest control ought not to be ignored and should attract the interest of future studies [82].

The nematocidal activity of hydrolates of Lavandula intermedia, L. luisieri, Thymus vulgaris and T. zygis was investigated against root-knot nematode Meloidogyne javanica. In vivo tests on tomato seedlings at sublethal doses of the hydrolates induced a significant reduction of nematode infectivity. In pot experiments, all hydrolates tested on tomato plants significantly affected the infection frequency and reproduction rate of the nematode population. This study demonstrated that hydrolates could be an exploitable source of the potential waste protection products on root-knot nematodes [83].

Chemical herbicides generally used to control weeds have harmful effects on the environment. Therefore, natural compounds which can be used as a bio herbicide are preferred to replace chemical. The phytotoxic activities of the Halophyllum tuberculatum hydrolate were evaluated against Triticum aestivum and Raphanus sativus seed. It was established that these cultivated plants are resistant to the application of $H$. tuberculatum hydrolates and showed high speed germination. It could be concluded that hydrolates of this plant can be used as biological herbicide with $T$. aestivum and $R$. sativus. Furthermore, hydrosoluble compounds can improve the possibilities of applying them as bioherbicides in the future [84]. The effects of different concentrations of Ocimum basilicum hydrolate on germination rate and shoot and root length of $O$. basilicum and Chenopodium quinoa seeds have been investigated, too. The results show that all the germination of $O$. basilicum and $C$. quinoa seeds were significantly inhibited under laboratory conditions [85].

Another research was conducted with hydrolates of Ipomea carnea leaves and flowers and Lantana camera leaves focusing on their effect on the growth of wheat, maize and cotton for 15 days. The hydrolate of $I$. carnea flowers can be suited as a fertilizer for maize plants in limited doses [86]. Since hydrolates have low toxicity, they are biodegradable and inexpensive to produce; the possibility of developing hydrolates for use in crop protection may be attractive [87].

Toxicity

Determination of safety study on Cyprinus caprio showed that $0.05 \mathrm{ml} \mathrm{L}^{-1}$ doses of Eucalyptus camaldulensis 
hydrolate do not create any kind of mental disorder. In fish exposed to 0.10 and $0.15 \mathrm{ml} \mathrm{L}^{-1}$ doses, some mental disorders were observed (rolling, numbness) at the end of $5 \mathrm{~h}$, mortality in the trial fish has been determined [88]. In another study, lethal concentration values of Cinnamomum zeylanicum on $C$. caprio were investigated. The results indicated that the hydrolate caused swimming changes, lethargy, lack of breath and leaning towards the depth of the aquariums at all concentrations, while the $1 \mathrm{~h}$ lethal concentration value of the safe dose of C. zeylanicum hydrolate was estimated at $4.39 \%$ [89]. Better survival of tambaqui (Colossomam acropomum) juveniles was achieved by adding $5 \%$ of Lippia alba hydrolate during simulated transport. Based on these findings, it is suggested that $5 \%$ of $L$. alba hydrolate is an effective sedative in the aquaculture management [90].

\section{Storage}

Because of the small concentration of the essential oil dissolved in hydrolates, they are subjected to microbiological proliferation. The reasons for spoilage have to be found in the nature of substrates supporting growth and of microbiological contaminants. Non-volatile watersoluble organic compounds (thermally stable) were likely carried over during distillation by a priming and foaming effect and could be used as nutrients by microorganisms. Contamination by mesophilic bacteria and yeast was observed in the hydrolates [91]. Microbial proliferation at room temperature is commonly observed in hydrolates when stored in a non-sterile container [92]. However, the essential oil concentration in hydrolates or cold storage are not sufficient to ensure microbiological stability. Additional hurdles such as chemical preservatives or aseptic packaging will be necessary to ensure microbial stability [93].

\section{Conclusion}

Hydrolates have widely been used in cosmetic industry as replacements for water in lotions, creams, soaps, tonics. Hydrolates can be used in drinks, for flavoring fruit beverages, confectioneries and soft drinks, for food preservation and as a convenient sanitizing agent during the washing of fresh-cut fruits and vegetables. Furthermore, they can be used in organic agriculture for decreased post-harvest loses during storage, as well as in the field production as nematocidal agents, or for weed control. However, their popularity is still on the rise, especially in aromatherapy.

\section{Acknowledgements}

This research was supported by the Ministry of Education, Science and Technological Development of the Republic of Serbia, grant number: 451-03-68/202014/200032.

\section{References}

[1] A.E. Edris, Identification and absolute quantification of the major water-soluble aroma components isolated from the hydrosols of some aromatic plants, Journal of Essential Oil Bearing Plants, 12(2009) 155-161.

[2] R.S. Verma, Distillate water: overlooked golden drops, Medicinal and Aromatic Plants, 1(2012) 3.

[3] A. Hamedi, M. Afifi, H. Etemadfard, Investigating chemical composition and indications of hydrosol soft drinks (aromatic waters) used in Persian folk medicine for women's hormonal and reproductive health conditions, Journal of Evidence-Based Complementary and Alternative Medicine, 22(2017) 824-839.

[4] R.B.R. Rajeswara, Hydrosols and water-soluble essential oils of aromatic plants: Future economic products, Indian perfumer, 56 (2012) 29-33.

[5] R.S. Verma, R.C. Padalia, A. Chauhan, Analysis of the hydrosol aroma of Indian oregano, Medicinal and Aromatic Plants, 1(2012) 7.

[6] R.B.R. Rajeswara, P.N. Kaul, K.V. Syamasundar,S. Ramesh, Water soluble fractions of rose-scented geranium (Pelargonium species) essential oil, Bioresource Technology, 84(2002) 243-246.

[7] A. Wajs-Bonikowska, M. Sienkiewicz, A. Stobiecka, A. Maciag, L. Szoka, E. Karna, Chemical composition and biological activity of Abies alba and $A$. koreana seed and cone essential oils and characterization of their seed hydrolates, Chemistry and Biodiversity, 12 (2015) 407418.

[8] S. D'Amato, A. Serio, C. Chaves Lopez, A. Paparella, Hydrosols: Biological activity and potential as antimicrobials for food applications, Food Control, 86(2018) 126-137.

[9] H. Baydar, M.K. Sangun, S. Erbas, N. Kara, Comparison of aroma compounds in distilled and extracted products of sage (Salvia officinalis L.), Journal of Essential Oil Bearing Plants, 16(2013) 39-44.

[10] F.X. Garneau, G. Collin, H. Gagnon, A. Pichette, Chemical composition of the hydrosol and the essential oil of three different species of the Pinaceae family: Picea glauca (Moench) Voss., Picea mariana (Mill.) B.S.P., and Abies balsamea (L.) Mill., Journal of Essential Oil Bearing Plants, 15(2012) 227-236.

[11] F.X. Garneau, G. Collin, H. Gagnon, Chemical composition and stability of the hydrosols obtained during essential oil production. I. The case of Melissa officinalis L. and Asarum canadense L.,American Journal of Essential Oils and Natural Products, 2(2014) 54-62.

[12] G. Collin, H. Gagnon, Chemical composition and stability of the hydrosol obtained during the production of essential oils. III. The case of Myrica gale L., Comptonia peregrine (L.) Coulter and Ledum groenlandicum Retzius, American Journal of Essential Oils and Natural Products, 4(2016) 07-19.

[13] F.X. Garneau, G. Collin, H. Gagnon, Chemical composition and stability of the hydrosols obtained during essential oil production. II. The case of Picea glauca (Moench) Voss., Solidago puberula Nutt., and Mentha piperita L., American Journal of Essential Oils and Natural Products, 2(2014) 29-35.

[14] S. Aazza, B. Lyoussi, M.G. Miguel, Antioxidant activity of eight hydrosols from Morocco, Asian Journal of Plant Sciences, 11(2012) 137-142. 
[15] Z.M. Mohammad, S. Amirhossein,E. Hamed, M. Mahmoodreza, Trachyspermum ammi hydrosol, an almost pure source of thymol; analysis of the recovered essential oil from different samples, International Journal of Pharmacognosy and Phytochemical Research, 7(2015) 457-460.

[16] N. Zekri, S. Amalich, M.A. Elbelghiti, T. Zair, Phytochemical screening and chemical composition of essential oils and hydrosols of Mentha species from Morocco, Advances in Environmental Biology, 8(2014) 10-18.

[17] G. Collin, H. Gagnon,A. St-Gelais, M. Turcotte, Composition of the essential oil and hydrosol of the roots of Ligusticum porteri, American Journal of Essential Oils and Natural Products, 1(2014) 4-10.

[18] F. Ghavidel, M. Zarshenas, Y. Ghasemi, A. Gholami, A. Sakhteman, P. Faridi, Impact of two different extraction methods on chemical composition and antimicrobial activities of multi-ingredients essential oils and hydrosols, Trends in Pharmaceutical Sciences, 4 (2018) 161-176.

[19] G. Lei, L. Wang, X. Liu, A. Zhang, Chemical composition of essential oils and hydrosols from fresh flowers of Cerasus subhirtella and Cerasus serrulatafrom East China, Natural Product Research, 28(2014) 1923-1925.

[20] C.S. Tavares, A. Martins, M.L. Faleiro, M.G. Miguel, L.C. Duarte, J.A. Gameiro, L.B. Roseiro, A.C. Figueiredo, Bioproducts from forest biomass: essential oils and hydrolates from wastes of Cupressus lusitanica Mill. and Cistus ladanifer L., Industrial Crops and Products, 144(2020) 112034.

[21] A.T. Zatla, M.E.A. Dib, N. Djabou, F. Ilias, J. Costa, A. Muselli, Antifungal activities of essential oils and hydrosol extracts of Daucus carota subsp. Sativus for the control of fungal pathogens, in particular gray rot of strawberry during storage, Journal of Essential Oil Research, 29(2017) 391-399.

[22] E.H.B. Ndiaye, M.T. Gueye, I. Ndiaye, S.M. Diop, M.B. Diop, M.L. Fauconnier, G. Lognay, Chemical composition of essential oils and hydrosols of three Eucalyptus species from Senegal: Eucalyptus alba Renv, Eucalyptus camaldulensis Dehnh and Eucalyptus tereticornis Hook., American Journal of Essential Oils and Natural Products, 5(2017) 01-07.

[23] F. leri, L. Cecchi, E. Giannini, C. Clemente, A. Romani, GC-MS and HS-SPME-GC $\times$ GC-TOFMS determination of the volatile composition of essential oils and hydrosols (by-products) from four species cultivated in Tuscany, Molecules, 24 (2019) 226.

[24] P.D.L. Lira, D. Retta, E. Tkacik, J. Ringuelet, J.D. Coussio, C.V. Baren, A.L. Bandoni, Essential oil and by products of distillation of bay leaves (Laurus nobilis L.) from Argentina, Industrial Crops and Products, 30 (2020) 259-264.

[25] R. Prusinowska, K. Smigielski, A. Kunicka-Styczynska, Hydrolates from lavender (Lavandula angustifolia) chemical composition, antimicrobial and antioxidant properties, PhD Interdisciplinary Journal, 3(2013) 33-39.

[26] K. Smigielski, A. Raj, K. Krosowiak, R. Gruska, Chemical composition of the essential oil of Lavandula angustifolia cultivated in Poland, Journal of Essential Oil Bearing Plants, 12 (2009) 338-347.

[27] H. Baydar, S. Kineci, Scent composition of essential oil, concrete, absolute and hydrosol from lavandin (Lavandula $x$ intermedia Emeric ax Loisel.), Journal of Essential Oil Bearing Plants, 12(2009) 131-136.

[28] S. Garzoli, S. Petralito, E. Ovidi, G. Turchetti, V.L. Masci,
A. Tiezzi, J. Trilli, S. Cesa, M.A. Casadei, P. Giacomello, P. Paolicelli, Lavandula $\times$ intermedia essential oil and hydrolate: evaluation of chemical composition and antibacterial activity before and after formulation in nanoemulsion, Industrial Crops and Products, 145 (2020) 112068.

[29] Y.O. Hay, M.A. Abril-Sierra, L.G. Sequeda-Castaneds, C. Bonnafous, C. Raynaud, Evaluation of combinations of essential oils and essential oils with hydrosols on antimicrobial and antioxidant activities. Journal of Pharmacy and Pharmacognosy research, 6(2018) 216230.

[30] N. Ohtsu, Y. Kohari,M. Gotoh, R. Yamada, Y. Nagata, M. Murata, Utilization of the Japanese peppermint herbal water byproduct of steam distillation as an antimicrobial agent, Journal of Oleo Science, 67(2018) 1227-1233.

[31] S.M. Diop, M.T. Gueye, I. Ndiaye, E.H.B. Ndiaye, M.B. Diop, S. Heuskin, M.L. Fauconnier, G. Lognay, Chemical composition of essential oils and floral waters of Mentha longifolia (L.) Huds. from Senegal, American Journal of Essential Oils and Natural Products, 4(2016) 46-49.

[32] M.D. Vito, M.G. Bellardi, F. Mondello, M. Modesto, M. Michelozzi, F. Bugli, M. Sanguinetti, M.C. Sclocchi, M.L. Sebastiani, S. Biffi, L. Barbanti, P. Mattarelli, Monarda citriodora hydrolate vs essential oil comparison in several antimicrobial applications, Industrial Crops and Products, 128(2019) 206-212.

[33] C. Bellahsene, M. Bendahou, A. Khadir, F. Zenati, F. Benbelaid, N. Aissaoui, A. Muselli, J. Costa, Antimicrobial activity and chemical composition of essential oil and hydrosol extract of Nepeta nepetella subsp. amethystine (Poir.) Briq. from Algeria, Journal of Applied Pharmaceutical Science, 5(2015) 21-25.

[34] N. Francezon, T. Stevanovic, Chemical composition of essential oil and hydrosol from Picea mariana bark residue, Bio Resources, 12(2017) 2635-2645.

[35] L.R. Riani, A.L. Macedo, L.M. Chedier, D.S. Pimenta, Chemical analysis of essential oil and hydrolates of leaves, inflorescences and stems of Piper chimonathifolium Kunth, Revista Virtual de Quimica, 9(2017) 1560-1569.

[36] R. Lemouchi, C. Selles, M. El Amine Dib, N. Benmansour, A. Allal, B. Tabti, K. Ouali, Chemical composition and antioxidant activity of essential oil and hydrosol extract obtained by hydrodistillation (HY) and liquid-liquid extraction (LLE) of Psoralea bituminosa, Journal of Herbs, Spices and Medicinal Plants, 23(2017) 299-307.

[37] S. Ulusoy, G. Bosgelmez-Tinaz, H. SecilmisCanbay, Tocopherol, carotene, phenolic contents and antibacterial properties of rose essential oil, hydrosol and absolute,Current Microbiology, 59(2009) 554-558.

[38] N. Maruyama, S. Tansho-Nagakawa, C. Miyazaki, K. Shimomura, Y. Ono, S. Abe, Inhibition of neutrophil adhesion and antimicrobial activity by diluted hydrosol prepared from Rosa damascene, Biological and Pharmaceutical Bulletin, 40 (2017) 161-168.

[39] K. Tomi, M. Kitao, N. Konishi, H. Murakami, Y. Matsumura, T. Hayashi, Enantioselective GC-MS analysis of volatile components from rosemary (Rosmarinus officinalis L.) essential oils and hydrosols, Bioscience, Biotechnology and Biochemistry, 80(2016) 840-847.

[40] A. Koutsoulas, A. Böszörményi, É.B. Héthelyi, E. HáznagyRadnai, J. Tóth, S. Czigle, Analysis of volatile constituents of Sideritis raeseri, Planta Medica, 81(2015)38.

[41] F. Karampoula, E. Giaouris, J. Deschamps, A.I. 
Doulgeraki, G.J.E. Nychas, F. Dubois-Brissonnet, Hydrosol of Thymbra capitata is a highly efficient biocide against Salmonella enterica serovar typhimurium biofilms, Applied and Environmental Microbiology, 82(2016) 53095319.

[42] L. Tabti, M.E.A. Dib, N. Djabou, N.G. Benyelles, J. Paolini, J. Costa, A. Muselli, Control of fungal pathogens of Citrus sinensis L. by essential oil and hydrosol of Thymus capitatus L, Journal of Applied Botany and Food Quality, 87(2014) 279-285.

[43] A. Marino, A. Nostro, N. Mandras, J. Roana, G. Ginestra, N. Miceli, M.F. Taviano, F. Gelmini, G. Beretta, V. Tullio, Evaluation of antimicrobial activity of the hydrolate of Coridothymus capitatus (L.) Reichenb. Fil. (Lamiaceae) alone and in combination with antimicrobial agents, BMC Complementary Medicine and Therapies, 20(2020) 89.

[44] H.C. Andola, V.K. Purohit, R.S. Chauhan, K. Arunachalam, Standardize quality standards for aromatic hydrosols, Medicinal Plants - International Journal of Phytomedicines and Related Industries, 6(2014) 161-162.

[45] O. Sagdic, Sensitivity of four pathogenic bacteria to Turkish thyme and oregano hydrosols, LebensmittelWissenschaft und Technologie, 36(2003) 467-473.

[46] A.I. Al-Turki, Antibacterial effect of thyme, peppermint, sage, black pepper and garlic hydrosols against Bacillus subtilisand Salmonella enteritidis, Journal of Food, Agriculture and Environment, 5(2007) 92-94

[47] A. Acheampong, L.S. Borquaye, S.O. Acquaah, J. OseiOwusu, G.K. Tuani, Antimicrobial activities of some leaves and fruit peels hydrosols, International Journal of Chemical and Biomolecular Science, 1(2015) 158-162.

[48] O. Sagdıc, M. Ozcan, Antibacterial activity of Turkish spice hydrosols, Food Control, 14 (2003) 141-143.

[49] S. Inouye, M. Takahashi, S. Abe, Inhibitory activity of hydrosols, herbal teas and related essential oils against filament formation and the growth of Candida albicans, Japanese Journal of Medical Mycology, 50 (2009) 243251.

[50] B. Wojcik-Stopczynska, P. Jakowienko, The estimation of antifungal activity of essential oil and hydrosol obtained from wrinkled-leaf mint (Mentha crispa L.), Herba Polonica,8 (2012) 5-15.

[51] X. Shen, W. Chen, Y. Zheng, X. Lei, M. Tang, H. Wang F. Song, Chemical composition, antibacterial and antioxidant activities of hydrosols from different parts of Areca catechu L. and Cocos nucifera L, Industrial Crops and Products, 96(2017) 110-119.

[52] M. Dubey, S. Sharma, R. Sengar, S. Bhadauria, R.K Gautam, In vitro antibacterial activity of Lantana camara leaves hydrosol, Journal of Pharmacy Research, 4(2011) 3972-3974.

[53] N.G. Chorianopoulos, E.D. Giaouris, P.N. Skandamis, S.A. Haroutounian, G.J.E. Nychas, Disinfectant test against monoculture and mixed-culture biofilms composed of technological, spoilage and pathogenic bacteria: bactericidal effect of essential oil and hydrosol of Satureja thymbra and comparison with standard acid-base sanitizers, Journal of Applied Microbiology, 104(2008) 1586-1596.

[54] K. Kaewprom, Y.H. Chen, C.F. Lin, M.T. Chiou, C.N. Lin, Antiviral activity of Thymus vulgaris and Nepeta cataria hydrosols against porcine reproductive and respiratory syndrome virus, Thai Journal of Veterinary Medicine, 47(2017) 25-33.
[55] N.H.L. Abdullah, S. Moosa, Characterisation of gaharu hydrosol: physical, chemical and microbiological properties, Research and Development Seminar, Bangi, Malaysa, 2010.

[56] S. Aazza, B. Lyoussi, M.G. Miguel, Antioxidant activity of some Morrocan hydrosols, Journal of Medicinal Plants Research,5(2011) 6688-6696.

[57] T.S. Cid-Pérez, R. Ávila-Sosa, C.E. Ochoa-Velasco, B.E. Rivera-Chavira, G.V. Nevárez-Moorillón, Antioxidant and antimicrobial activity of Mexican oregano (Poliomintha longiflora) essential oil, hydrosol and extracts from waste solid residues, Plants, 8(2019) 22.

[58] E.Y. Ko, S.H. Cho, K. Kang, G. Kim, J.H. Lee, Y.J. Jeon, D. Kim, G. Ahn, K.N. Kim, Anti-inflammatory activity of hydrosols from Tetragonia tetragonoides in LPS-induced RAW 264.7 cells, Experimental and Clinical Sciences, International Online Journal for Advances in Sciences (EXCLI Journal), 16 (2017) 521-530.

[59] E.M. Yayla, N. Izgu, L. Ozdemir, S.A. Erdem, M. Kartal, Sage tea-thyme-peppermint hydrosol oral rinse reduces chemotherapy-induced oral mucositis: A randomized controlled pilot study, Complementary Therapies in Medicine, 27(2016) 58-64.

[60] A. Hamedi, S.M. Moheimani, A. Sakhteman, H. Etemadfard, M. Moein, An overview on indications and chemical composition of aromatic waters (hydrosols) as functional beverages in Persian nutrition culture and folk medicine for hyperlipidemia and cardiovascular conditions, Journal of Evidence-Based Complementary and Alternative Medicine, 22(2017) 544-561.

[61] A. Hamedi, A. Pasdaran, Z. Zabarjad, M. Moein, A survey on chemical constituents and indications of aromatic waters soft drinks (hydrosols) used in Persian nutrition culture and folk medicine for neurological disorders and mental health, Journal of Evidence-Based Complementary and Alternative Medicine, 22(2017) 744-752.

[62] H.R. Monsef-Esfahani, Y. Amanzade, Z. Alhani, H. Hajimehdipour, M.A. Faramarzi, GC/MS analysis of Citrus aurantium $\mathrm{L}$. hydrolate and its comparison with the commercial samples, Iranian Journal of Pharmaceutical Research, 3(2004) 177-179.

[63] A. Kunicka-Styczynska, K. Smigielski, R. Prusinowska, K. Rajkowska, B. Kusmider, M. Sikora, Preservative activity of lavender hydrosols in moisturizing body gels, Letters in Applied Microbiology, 60(2014) 27-32.

[64] I. Ozturk, F. Tornuk, O. Caliskan-Aydogan, M.Z. Durak, O. Sagdic, Decontamination of iceberg lettuce by some plant hydrosols, LWT - Food Science and Technology, 74(2016) 48-54.

[65] A. Lante, F. Tinello, Citrus hydrosols as useful by-products for tyrosinase inhibition, Innovative Food Science and Emerging Technologies, 27(2015) 154-159.

[66] P. Xylia, A. Clark, A. Chrysargyris, G. Romanazzi, Quality and safety attributes on shredded carrots by using Origanum majorana and ascorbic acid, Postharvest Biology and Technology, 155(2019) 120-129.

[67] F. Tornuk, E. Dertli, Decontamination of Escherichia coli 0157:H7 and Staphylococcus aureus from fresh-cut parsley with natural plant hydrosols, Journal of Food Processing and Preservation, 39(2015) 1587-1594.

[68] F. Tornuk, I. Ozturk, O. Sagdic, A. Yilmaz, O. Erkmen, Application of predictive inactivation models to evaluate survival of Staphylococcus aureusin fresh-cut apples treated with different plant hydrosols, International Journal 
of Food Properties, 17(2014) 587-598.

[69] F. Tornuk, H. Cankurt, I. Ozturk, O. Sagdic, O. Bayram, $\mathrm{H}$. Yetim, Efficacy of various plant hydrosols as natural food sanitizers in reducing Escherichia coli 0157:H7 and Salmonella typhimuriumon fresh cut carrots and apples,International Journal of Food Microbiology, 148(2011) 30-35.

[70] O. Sagdic, I. Ozturk, F. Tornuk, Inactivation of non-toxigenic and toxigenic Escherichia coli 0157:H7 inoculated on minimally processed tomatoes and cucumbers: utilization of hydrosols of Lamiaceae species as natural food sanitizers, Food Control, 30(2013) 7-14.

[71] N. Oral,L. Vatansever, A. Güven, M. Gülmez, Antibacterial activity of some Turkish plant hydrosols, Kafkas Universitesi Veteriner Fakultesi Dergisi, 14(2008) 205209.

[72] I. Ozturk, Antifungal activity of propolis, thyme essential oil and hydrosol on natural mycobiota of suck, a Turkish fermented sausage: monitoring of their effects on microbiological, color and aroma properties, Journal of Food Processing and Preservation, 39(2015) 1148-1158.

[73] J.S. Garcia-Romo, M.S. Yepiz-Gomez, M. PlascenciaJatomea, H.D.C. Santacruz-Ortega, A. Burgos-Hernandez, J.R.G.D. Leon, F.J. Cinco-Moroyoqui, J. Borboa-Flores, Compounds with in vitro antibacterial activity from hydrosol of Lippia palmeri and morphometric changes on Listeria monocytogenes, BioTecnia, 20(2017) 35-42.

[74] R. Kumar, J. Atanu, D. Ankit, P. Satish, Suitability of type of herb and its form as flavouring in herbal ice cream, International Journal of Chemical Studies, 6(2018) 15621567.

[75] Z. Didar, Effects of coatings with pectin and Cinnamomum verum hydrosol included pectin on physical characteristics and shelf life of chicken eggs stored at $30{ }^{\circ} \mathrm{C}$, Nutrition and Food Sciences Research, 6(2019) 39-45.

[76] N. Zekri, N. Handaq, A.E. Caidi, T. Zair, M.A.E. Belghiti, Insecticidal effect of Mentha pulegium L. and Mentha suvaleolens Erh. hydrosols against a pest of citrus, Taxoperta aurantii (Aphididae), Research on Chemical Intermediates, 42(2016) 1639-1649.

[77] N. Hossein, Z. Zahra, M. Abolfazl, S. Mahdi, K. Ali, Effect of Cinnamon zeylanicum essence and distillate on clotting time, Journal of Medicinal Plants Research, 7(2013) 1339-1343.

[78] C. Stan, A. Muscalu, V.N. Vladut, F. Israel-Roming, Allelophatic potential of volatile/essential oils and hydrosols obtained from cultured medicinal plants, Scientific Bulletin, Series F, Biotechnologies, 22(2018) 34-41.

[79] N. Boyraz, M. Ozcan, Inhibition of phytopathogenic fungi by essential oil, hydrosol, ground material and extract of summer savory (Satureja hortensis L.) growing wild in Turkey, International Journal of Food Microbiology, 107(2006) 238-242.

[80] N. Boyraz, M. Ozcan, Antifungal effect of some spice hydrosols, Fitoterapia, 76(2005) 661-665.

[81] N. Boyraz, M. Ozcan, In vitro inhibition of Sclerotinia sclerotiorum and Colletotrichum circinans by summer savory (Satureja hortensis L.) derivates, Journal of Essential Oil Bearing Plants, 9(2006) 107-117.

[82] E.A. Petrakis, A.C. Kimbaris, D.P. Lykouressis, M.G. Polissiou, D.C. Perdikis, Hydrosols evaluation in pest control: insecticidal and settling inhibition potential against Myzus persicae (Sulzer), Journal of Applied Entomology, 139(2015)260-267.
[83] M.F. Andres, A. Gonzales-Coloma, R. Munoz, F.D. Pena, L.F. Julio, J. Burillo, Nematocidal potential of hydrolates from the semi industrial vapour-pressure extraction of Spanish aromatic plants, Environmental Science and Pollution Research, 25(2018) 29834-29840.

[84] A. Hamdi, K. Majouli, Y.V. Heyden, G. Flamini, Z. Marzouk, Phytotoxic activities of essential oils and hydrosols of Haplophyllum tuberculatum, Industrial Crops and Products, 97(2017) 440-447.

[85] M. Camlica, G. Yaldiz, F. Ozen, Effects of different basil hydrosol doses on the germination and shoot and root lengths of basil (Ocimum basilicum) and quinoa (Chenopodium quinoa) seeds, Indian Journal of Pharmaceutical Education and Research, 51(2017) S254-S257.

[86] V.B. Suradkar, B.B. Wankhade, M.S. Talreja, P.D. Ochani, Effect of hydrosol of Ipomea carnea leaves, flowers and Lantana camera leaves on the growth of wheat, maize and cotton plant, International Journal of Pharmaceutical Sciences and Research, 7(2016) 3477-3479.

[87] R. Belabbes, M.E.A. Dib, N. Djabou, F. Ilias, B. Tabti, J. Costa, A. Muselli, Chemical variability, antioxidant and antifungal activities of essential oils and hydrosol extract of Calendula arvensis L. from Western Algeria, Biochemistry and Biodiversity, 14(2017) e1600482.

[88] B. Altinterim, A. K. Gulec, O. Aksu, Determination of safety dose of Eucalyptus camaldulensis hydrosol on mirror carp (Cyprinus caprio), Fresenius Environmental Bulletin, 21(2012) 1219-1222.

[89] K.A. Gulec, B. Altinterim, O. Aksu, Determination of lethal concentration (LC50) values of Cinnamomum zeylanicum hydrosol on carp fish, Iranian Journal of Fisheries Sciences, 12(2013) 34-44.

[90] H.N.P. Silva, E.M.O. Sousa, J.L.S. Maia, M.T.L. Pinheiro, S.V.O.C. Lameirao, R.H.V. Mourao, J.G.S. Maia, B. Baldisserotto, L.V.F. Silva, Lippia alba (Verbenaceae) hydrolate as sedative of tambaqui (Colossoma macropomum) juveniles in simulated transport conditions, Aquaculture Research, 49 (2018) 128-134.

[91] I. Alavi, M. Zahedi, M. Zahedi, A. Ghasemi Pirbalouti, E. Rahimi, H. Momtaz, Evaluating the microbial contamination of some Iranian dried medicinal plants and distillates, International Journal of Epidemiologic Research, 4(2017) 118-124.

[92] J. Janarthan, S. Grivot, T. Talou, Fast quality control method for aromatic waters: identification of roses hydrosols spoiled by microorganisms based on detection of associated volatiles, Natural Volatiles and Essential Oils, 4(2017) 116.

[93] C. Labadie, C. Ginies, M.H. Guinebretiere, M.G.C. Renard, C. Cerutti, F. Carlin, Hydrosols of orange blossom (Citrus aurantium) and rose flower (Rosa damascena and Rosa centifolia) support the growth of a heterogeneous spoilage microbiota, Food Research International, 76(2015)576586. 


\section{HIDROLATI - NUSPROIZVODI PRILIKOM DESTILACIJE ETARSKIH ULJA: HEMIJSKI SASTAV, BIOLOŠKA AKTIVNOST I MOGUĆNOSTI UPOTREBE}

Milica G. Aćimović ${ }^{1}$, Vele V. Tešević2 ${ }^{2}$ Katarina T. Smiljanić ${ }^{2}$, Mirjana T. Cvetković ${ }^{3}$, Jovana M. Stanković ${ }^{3}$, Biljana M. Kiprovski ${ }^{1}$, Vladimir S. Sikora ${ }^{1}$

${ }^{1}$ Institut za ratarstvo i povrtarstvo, Novi Sad, Srbija

2Univerzitet u Beogradu, Hemijski fakultet, Beograd, Srbija

3 Univerzitet u Beogradu, Institut za hemiju, tehnologiju i metalurgiju, Beograd, Srbija

Hidrolati, koji se takođe nazivaju i hidrosoli, cvetne ili aromatične vode, kao i destilati, proizvode se u procesu destilacije etarskih ulja vodenom parom. Mala količina etarskog ulja nalazi se rastvorena u hidrolatima dajući im specifične organoleptičke osobine i ukus, kao i biološku aktivnost, što ih čini korisnim kao sirovinu u mnogim industrijama. Njihova popularnost poslednjih godina raste, posebno u aromaterapiji. Cilj ovog preglednog rada je da se analizira hemijski sastav hidrolata i njihovih etarskih ulja, kao i biološku aktivnost hidrolata (antimikrobna, antioksidativna i antiinflamatorna), ali i mogućnosti upotrebe, ne samo u prehrambenoj industriji kao prirodnih aroma i konzervanasa sveže isečenog voća i povrća, ali i funkcionalnih (bezalkoholnih) napitaka. Takođe, hidrolat i mogu da se koriste u aromaterapiji i kozmetici kao i u organskoj poljoprivredi i ribarstvu.
(PREGLEDNI RAD)

UDK 66.048:665.52

DOI: $10.5937 /$ savteh2002054A

Ključne reči: Hidrolati, Hidrosoli, Aromatične vode, Cvetne vode, Destilati 